\title{
Strength of ERK1/2 MAPK Activation Determines Its Effect on Myelin and Axonal Integrity in the Adult CNS
}

\author{
Akihiro Ishii, ${ }^{1}$ Miki Furusho, ${ }^{1}$ Jeffrey L Dupree, ${ }^{2}$ and Rashmi Bansal ${ }^{1}$ \\ ${ }^{1}$ Department of Neuroscience, University of Connecticut Medical School, Farmington, Connecticut 06030, and 2Department of Anatomy and Neurobiology, \\ Virginia Commonwealth University, Richmond, Virginia 23298
}

Myelin growth is a tightly regulated process driven by multiple signals. ERK1/2-MAPK signaling is an important regulator of myelin thickness. Because, in demyelinating diseases, the myelin formed during remyelination fails to achieve normal thickness, increasing ERK1/2 activity in oligodendrocytes is of obvious therapeutic potential for promoting efficient remyelination. However, other studies have suggested that increased levels of ERK1/2 activity could, in fact, have detrimental effects on myelinating cells. Because the strength, duration, or timing of ERK1/2 activation may alter the biological outcomes of cellular responses markedly, here, we investigated the effect of modulating ERK1/2 activity in myelinating cells using transgenic mouse lines in which ERK1/2 activation was upregulated conditionally in a graded manner. We found enhanced myelin gene expression and myelin growth in the adult CNS at both moderate and hyperactivated levels of ERK1/2 when upregulation commenced during developmental myelination or was induced later during adulthood in quiescent preexisting oligodendrocytes, after active myelination is largely terminated. However, a late onset of demyelination and axonal degeneration occurred at hyperelevated, but not moderately elevated, levels regardless of the timing of the upregulation. Similarly, myelin and axonal pathology occurred with elevated ERK1/2 activity in Schwann cells. We conclude that a fine tuning of ERK1/2 signaling strength is critically important for normal oligodendrocyte and Schwann cell function and that disturbance of this balance has negative consequences for myelin and axonal integrity in the long term. Therefore, therapeutic modulation of ERK1/2 activity in demyelinating disease or peripheral neuropathies must be approached with caution.

Key words: myelin; oligodendrocyte; Schwann cells

Significance Statement

ERK1/2-MAPK activation in oligodendrocytes and Schwann cells is an important signal for promoting myelin growth during developmental myelination. Here, we show that, when ERK1/2 are activated in mature quiescent oligodendrocytes during adulthood, new myelin growth is reinitiated even after active myelination is terminated, which has implications for understanding the mechanism underlying plasticity of myelin in adult life. Paradoxically, simply increasing the "strength" of ERK1/2 activation changed the biological outcome from beneficial to detrimental, adversely affecting myelin and axonal integrity in both the CNS and PNS. Therefore, this study highlights the complexity of ERK1/2-MAPK signaling in the context of oligodendrocyte and Schwann cell function in the adult animal and emphasizes the need to approach potential therapeutic modulation of ERK1/2 activity with caution.

\section{Introduction}

Myelin is a multilamellar sheath generated by oligodendrocytes in the CNS and by Schwann cells in the PNS. Among its many

Received Jan. 26, 2016; revised May 8, 2016; accepted May 10, 2016.

Author contributions: A.I. and R.B. designed research; A.I. and M.F. performed research; A.I., J.D., and R.B. analyzed data; A.I. and R.B. wrote the paper.

This work was supported by the National Institutes of Health (Grants NS081948 and NS38878) and the National Multiple Sclerosis Society (Grant RG4878A4). We thank Dr. K.-A. Nave (Max Plank Institute, Gottingen, Germany) for providing the Cnp-Cre mice and C. Belisario, A. Khatri, and M. Dezhbord for technical assistance.

The authors declare no competing financial interests.

Correspondence should be addressed to Rashmi Bansal, PhD, Department of Neuroscience, University of Connecticut Medical School, 263 Farmington Ave., Farmington, CT 06030. E-mail: bansal@neuron.uchc.edu. functions are rapid impulse conduction, trophic support of axons, and serving as a form of neural plasticity for adaptation of brain functions to environmental stimuli (Fields, 2015; Simons and Nave, 2015). Damage to the myelin sheaths, as in multiple sclerosis, leads to severe neurological deficits. Although limited remyelination occurs in humans and rodents, the myelin sheath formed is thinner than normal (Ludwin and Maitland, 1984; Franklin, 2002). Further, the loss of axonal integrity, attributed in significant part to the loss of trophic support from oligodendro- 
cytes and myelin, is a major cause of long-term disability in multiple sclerosis (Trapp et al., 1998; Nave and Trapp, 2008). Therefore, it is critical to identify specific factors that promote efficient growth of the myelin sheath during remyelination and, conversely, to identify molecules and mechanisms that are crucial for the long-term axoglial interactions required for efficient neuronal functions during adulthood.

Recently, genetic loss- and gain-of-function studies have shown that ERK1/2-MAPK signaling in oligodendrocytes and Schwann cells is an important conserved mechanism that promotes both CNS and PNS myelin growth during developmental myelination (Ishii et al., 2012; Ishii et al., 2013; Sheean et al., 2014). Specifically, the gain-of-function studies showed that a modest increase of ERK1/2 activity in oligodendrocytes of heterozygous transgenic mice, with constitutively active Mek1 $(\mathrm{Mek} /+)$, an upstream activator of ERK1/2, resulted in increased myelin thickness during developmental myelination and during remyelination (Fyffe-Maricich et al., 2013; Ishii et al., 2013). Further, we showed recently that ERK1/2 continues to be expressed in myelin of adult mice and plays a key role in maintaining the integrity of myelin and axons throughout adult life (Ishii et al., 2014). These findings together indicate a therapeutic potential of elevating ERK1/2 activity for restoring normal myelin thickness and perhaps improving axonal survival in human demyelinating disease. However, it is believed that the biological outcome of ERK1/2 activation can depend on the strength, duration, and timing of ERK1/2 activation (Dikic et al., 1994; Ebisuya et al., 2005; Katz et al., 2007). Further, several studies have suggested that ERK1/2 activity could, in fact, have detrimental effects on oligodendrocytes and Schwann cells (Fressinaud et al., 1995; Bansal and Pfeiffer, 1997; Canoll et al., 1999; Harrisingh et al., 2004; Ogata et al., 2004; Napoli et al., 2012). Therefore, before investigating its therapeutic application, an important question to address is whether increasing the strength and/or altering the timing of ERK1/2 activation would result in increased but normal myelin growth or if it would lead to adverse effects on myelin and axonal integrity in the long term.

To address these questions, we generated and examined lines of transgenic mice in which ERK1/2 were upregulated conditionally in oligodendrocytes in a graded manner (Mek/+ and Mek/ $M e k)$, either commencing early during active developmental myelination or induced later during adulthood in quiescent oligodendrocytes, after active myelination is largely terminated. We found that, regardless of the time when ERK1/2 upregulation commenced, myelin gene expression and growth were enhanced at both the Mek gene dosages in the adult animals. However, a late onset of demyelination and axonal degeneration, accompanied by a partial loss of oligodendrocytes, significant inflammatory reaction, and neurological deficit, occurred only in the Mek/ Mek, not in the Mek/+ mice. Similarly, elevated ERK1/2 activity adversely affected myelinating Schwann cells in the adult mice. Together, these studies suggest that the strength of ERK1/2 activation plays a predominant role in determining the outcome of ERK1/2 activation.

\section{Materials and Methods}

Mouse lines

Rosa26StopFl ${ }^{\text {Mek1DD,EGFP }}$ mice (generated and described in Srinivasan et al., 2009) were appropriately crossed with $P l p C r e^{\mathrm{ERT}}$ transgenic mice (proteolipid protein; Jackson Laboratory; Doerflinger et al., 2003) in which Cre is induced by intraperitoneal injection of 4-hydroxytamoxifen (Tm; Sigma-Aldrich) to generate heterozygous and homozygous mice $\left(\mathrm{PlpCr}^{\mathrm{ERT}+1-} ;\right.$ Rosa26StopFl $l^{\mathrm{Mek} 1 \mathrm{DD}, \mathrm{EGFP} /+}$ and PlpCre $e^{\mathrm{ERT}+l^{-}}$;
Rosa26StopFl ${ }^{\text {Mek1DD, EGFP/Mek1DD, EGFP }}$, referred to as PlpCre ${ }^{\mathrm{ERT}} ; \mathrm{Mek} /+$ and $P l p C r e^{\text {ERT }} ; M e k / M e k$, respectively). The Rosa26StopFl ${ }^{\text {Mek1DD,EGFP }}$ mice were also crossed with Cnp ${ }^{\mathrm{Cre} /+}$ (Lappe-Siefke et al., 2003; 2' -3' cyclic nucleotide $3^{\prime}$-phosphodiesterase, CNP) to generate heterozygous and homozygous mice $\left(\mathrm{Cnp}^{\mathrm{Cre} /+} ;\right.$ Rosa26StopFl ${ }^{\mathrm{Mek} 1 \mathrm{DD}, \mathrm{EGFP} /+}$ and $\mathrm{Cn} p^{\mathrm{Cre} /+}$; Rosa26StopFl ${ }^{\text {Mek1DD , EGFP/Mek1DD, EGFP }}$, referred to here as CnpCre;Mek/+

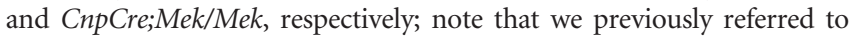
CnpCre;Mek/+ mice as CnpCre;MekDD in Ishii et al., 2013). In these transgenic mice, Cre-mediated excision of floxed STOP cassette leads to the expression of constitutively active Mek1 and enhanced green fluorescent protein (EGFP). This results in sustained activation of ERK1/2, downstream mediators of Mek1 in the MAPK pathway, in CNP- or proteolipid protein (PLP)-expressing oligodendrocyte and Schwann cells (Gravel et al., 1998; Yuan et al., 2002; Doerflinger et al., 2003; Leone et al., 2003). Littermate mice with no Cre were used as controls, facilitating comparisons among the genotypes. The tamoxifen-inducible $P l p C r e^{\text {ERT }}$ approach has allowed us to generate mice in which the Mekl gene is conditionally induced in a temporally controlled manner, thus providing us with a means to investigate the effect of overstimulation of ERK1/2 during developmental myelination after Tm injection at postnatal day 10 (P10) or during adulthood (2 months). Genotyping of different lines of mice of both sexes was performed by PCR analysis using the appropriate primers, as described previously (Furusho et al., 2011; Ishii et al., 2012, 2013, 2014).

\section{Immunolabeling and histology}

As described previously (Kaga et al., 2006; Furusho et al., 2012; Ishii et al., 2012), perfused (PBS or $4 \%$ paraformaldehyde/PBS) mice of both sexes were subjected to postfixation overnight in $4 \%$ paraformaldehyde/PBS and then another postfixation overnight in $20 \%$ sucrose/PBS. Cryostat transverse sections $(15 \mu \mathrm{m})$ of cervical spinal cord and longitudinal sections $(10 \mu \mathrm{m})$ of sciatic nerves were cut. Before immunolabeling with anti-phospho-ERK1/2 (1:400; Cell Signaling Technology), CC1 antibody (1:40; Millipore), anti-cleaved caspase-3 (1:100; Cell Signaling Technology), anti-glial fibrillary acidic protein (anti-GFAP, 1:1000; DAKO), or anti-IBA-1 (1:1000; Wako Chemicals), spinal cord sections were subjected to antigen retrieval by $5 \mathrm{~min}$ of incubation at $95^{\circ} \mathrm{C}$ in citrate buffer, $\mathrm{pH}$ 6.0, and $10 \mathrm{~min}$ at room temperature. Floating sections were used for EGFP/CC1 double labeling. Anti-GFP (1:200; Invitrogen) labeling was performed before antigen retrieval and labeling for CC1. Sections were incubated at $4^{\circ} \mathrm{C}$ for $24-72 \mathrm{~h}$ in primary antibodies and for $1 \mathrm{~h}$ with appropriate secondary antibodies conjugated to Alexa Fluor 488 (1:500; Invitrogen) or Cy3 (1:500; Jackson Immuno Research Laboratories) and nuclei were counterstained with Hoechst blue dye 3342 ( $1 \mathrm{mg} / \mathrm{ml}$; SigmaAldrich). For phospho-mTOR ${ }^{2448}$ immunolabeling, floating sections were incubated in $5 \%$ methanol/1\% $\mathrm{H}_{2} \mathrm{O}_{2}$ for $10 \mathrm{~min}$, followed by $10 \%$ Triton X-100 for $30 \mathrm{~min}$, and blocked in 10\% NGS for $1 \mathrm{~h}$. Incubation in phospho-mTOR ${ }^{2448}$ antibody (1:100; Cell Signaling Technology) diluted in $3 \%$ bovine serum albumin/0.02\% Triton X-100, was performed for $72 \mathrm{~h}$ at $4^{\circ} \mathrm{C}$. PBS or TBS containing $100 \mu \mathrm{M}$ sodium fluoride and $100 \mu \mathrm{M} o$-vanadate were used for dilutions and washes. In some cases, the avidin/biotinylated enzyme complex (ABC) system (Vector Laboratories) was used, and the color was developed by incubation in $\mathrm{DAB}$ (Sigma-Aldrich).

For Giemsa staining, Giemsa stock solution in glycerol (50\%) and methanol $(50 \%)$ was diluted in PBS. Longitudinal sections of sciatic nerves were incubated in the diluted solution $(0.1 \%$ Giemsa/2.5\% glycerol $/ 2.5 \%$ methanol/PBS) for $10 \mathrm{~min}$ at room temperature. After a 5-10 min wash in PBS, the sections were differentiated in $0.25 \%$ acetic acid. Masson's trichrome staining was performed as per the manufacturer's instructions (catalog \#25088; Abcam).

\section{In situ hybridization}

Transverse sections of cervical spinal cord were prepared as above and in situ hybridization was performed as described previously (Furusho et al., 2011; Furusho et al., 2012; Ishii et al., 2012) using riboprobes specific for PLP mRNA (Dr. W.B. Macklin, University of Colorado School of Medicine, Aurora, CO) or myelin basic protein (MBP) mRNA (Dr. M. Qiu, University of Louisville, Louisville, KY). Briefly, after incubation in $1 \mu \mathrm{g} / \mathrm{ml}$ proteinase $\mathrm{K}$ at $37^{\circ} \mathrm{C}$ for $30 \mathrm{~min}$, sections were hybridized over- 
night at $65^{\circ} \mathrm{C}$ with digoxigenin-labeled antisense cRNA probe and washed in $50 \%$ formamide, $2 \times \mathrm{SSC}$, and $1 \%$ SDS at $65^{\circ} \mathrm{C}$ for $2-3 \mathrm{~h}$, followed by rinses in $2 \times$ SSC and $0.2 \times$ SSC at room temperature, and $0.1 \times$ SSC at $60^{\circ} \mathrm{C}$. After blocking in $1 \%$ Tween 20 and $1 \%$ NGS for $1 \mathrm{~h}$, sections were incubated (overnight) in alkaline-phosphataseconjugated antidigoxigenin antibody (1:5000; Roche Diagnostics). Color was developed with 4-nitroblue tetrazolium chloride and 5-bromo-4-chloro-3-indolylphosphate.

\section{Electron microscopy}

Transgenic and littermate control mice of both sexes were perfused with $4 \%$ paraformaldehyde, $2 \%$ glutaraldehyde in $0.1 \mathrm{~m}$ cacodylate buffer, $\mathrm{pH}$ 7.4 (Electron Microscopy Sciences). Cervical spinal cords, optic nerves, and sciatic nerves of transgenic and littermate control mice were postfixed in $1 \% \mathrm{OsO}_{4}$. Samples were dehydrated through graded ethanol, stained en bloc with uranyl acetate, and embedded in Poly/Bed812 resin (Polysciences). Thin $(1 \mu \mathrm{m})$ sections were stained with toluidine blue and ultrathin $(0.1 \mu \mathrm{m})$ sections from matching areas of experimental and control tissue blocks were cut and visualized using an electron microscope (1200CX; JEOL) at $80 \mathrm{kV}$. For g-ratio analysis, between 100 and 400 axons were measured per genotype from matched regions of the ventral cervical spinal cord and optic nerve. Quantification of the area of oligodendrocyte cell bodies, the inner tongue, and associated cytoplasmic collars and the corresponding axons was done using the area measurement function in Adobe Photoshop. Statistical analysis was performed using Student's $t$ test. Counts of myelin/axon abnormalities in spinal cords and sciatic nerves was done from images of seminthin sections. Statistical analysis was performed using Student's $t$ test or one-way ANOVA.

Teased fibers were prepared from sciatic nerves dissected from gluteraldehyde perfused animals according to the procedure described by Viader et al. (2011) with slight modifications. Specifically, sciatic nerves were washed with $0.1 \mathrm{M}$ cacodylate buffer and then incubated in $1 \%$ osmium tetroxide and $1.5 \%$ potassium ferricyanide in $0.1 \mathrm{M}$ cacodylate buffer for $1 \mathrm{~h}$, followed by washes in PBS and incubation in 33\%, 66\%, and 100\% glycerol/PBS for $6 \mathrm{~h}$ each. Nerves were then treated with $0.6 \%$ Sudan black dissolved in $70 \%$ ethanol at room temperature for $30 \mathrm{~min}$, rinsed with $70 \%$ ethanol and water, and then placed back in $100 \%$ glycerol. Finally, nerves were teased in $100 \%$ glycerol and coverslipped for imaging.

\section{Quantitative real-time PCR ( $q R T-P C R)$}

Total RNA was extracted using the TRIzol reagent (Invitrogen) from spinal cords. Then, $1 \mu \mathrm{g}$ of total RNA was reverse transcribed to cDNA using the iScript Synthesis Kit (Bio-Rad) according to the manufacturer's instructions. qRT-PCR was performed using an Eppendorf Mastercycler ep realplex Thermal Cycler and the iQ SYBR Green Supermix (Bio-Rad) according to the manufacturer's instructions. The following primers were used: PLP forward primer, 5'-GTATAGGCAGTCTCTGCGCTGAT-3'; PLP reverse primer, 5' -AAGTGGCAGCAATCATGAAGG-3'; MBP forward primer, 5' TACCTGGCCACAGCAAGTAC-3'; MBP reverse primer, 5'-GTCA CAATGTTCTTGAAG-3'; myelin oligodendrocyte glycoprotein (MOG) forward primer, 5'-CTGTTCTTGGACCCCTGGTT-3'; MOG reverse primer, 5'-ACCTGCTGGGCTCTCCTT-3'; myelin-associated glycoprotein (MAG) forward primer, 5' -TGCTCACCAGCATCCTCACG-3'; MAG reverse primer, 5'-AGCAGCCTCCTCTCAGATCC-3'; GAPDH forward primer, 5' -TGTGTCCGTCGTGGATCTG-3'; GAPDH reverse primer, 5' CATGTAGGCCATGAGGTCCACCAC-3'. qRT-PCR conditions were as follows: denaturation at $95^{\circ} \mathrm{C}$ for $30 \mathrm{~s}$, primer annealing at $55.5^{\circ} \mathrm{C}$ for $30 \mathrm{~s}$, and elongation at $72^{\circ} \mathrm{C}$ for $40 \mathrm{~s}$. Quantification of PCR products was performed using the 2- $\Delta \Delta \mathrm{Ct}$ method. Quantities of mRNA were normalized to the housekeeping gene GAPDH.

\section{Immunoblotting}

Immunoblotting was performed as described previously (Fortin et al., 2005). Briefly, equal amounts of total proteins from lysates of spinal cord white matter and whole sciatic nerves were loaded onto SDS-PAGE, transferred to PVDF membranes, and immunolabeled for phosphoERK1/2 (1:10,000; Cell Signaling Technology) or phospho-mTOR ${ }^{2448}$ (1:1000; Cell Signaling Technology) and GAPDH (1:60,000; Biodesign International) as a loading control. Quantification of the bands was done by ImageJ software. Statistical analysis used to evaluate immunoblots was done by one-way ANOVA test.

\section{Motor function tests}

Rotarod test. Motor function tests were performed according to Crawley (2007) with slight modifications as described below. Mice of both sexes were trained for 2 trials ( $120 \mathrm{~s}$ each) on the rotarod at a constant speed (3 rpm). Subsequent test runs consisted of 3 trials on an accelerating rotarod for up to $300 \mathrm{~s}$ (starting at $3 \mathrm{rpm}$, accelerating to a final speed of 30 $\mathrm{rpm})$. Mice were returned to their home cages for at least $15 \mathrm{~min}$ between trials.

Wire-hanging test. Mice of both sexes were placed on a wire grid, which was then inverted over the home cage. The latency to when the animals fell was recorded (in seconds). The performance for each animal was presented as the average of three trials. Statistical analysis of the data from both these tests was done using two-tail Student's $t$ test.

Footprint analysis. The hindpaws of the mouse were dipped in paint. The mouse was made to walk on a white paper along a narrow corridor to a goal box. An imprint of footprints was left on the paper as the mouse walked, giving an indication of its gait.

\section{Results}

Increase in constitutively active Mek1 gene dosage correlates with graded increase in ERK1/2 activity and EGFP expression in oligodendrocytes

We generated transgenic mice that expressed one or both alleles of constitutively active Mek1 (and EGFP) conditionally to overactivate ERK1/2 in oligodendrocytes in a gene-dosage-dependent manner. We used both the CnpCre and the Tm-inducible PlpCre ${ }^{\text {ERT }}$ lines of mice to generate CnpCre;Mek/+, CnpCre; Mek/Mek and PlpCre ${ }^{\mathrm{ERT}} ; \mathrm{Mek} /+, \mathrm{PlpCre}{ }^{\mathrm{ERT}} ; \mathrm{Mek} / \mathrm{Mek}$ mice.

To validate that there was a dose-dependent increase of Mek1/ EGFP and ERK1/2 activity in oligodendrocytes, we first examined spinal cord sections from control, CnpCre;Mek/+, and CnpCre; Mek/Mek mice for EGFP expression (Fig. 1A, top). As expected, EGFP signal intensity was elevated incrementally in the oligodendrocyte-like cells of the white matter in the adult CnpCre; Mek/+ and CnpCre;Mek/Mek, but not in the control mice. We have shown previously that EGFP has a complete overlap (99\%) with the oligodendrocyte marker $\mathrm{CC} 1$ in the spinal cords of CnpCre;Mek/+ mice (Ishii et al., 2014), indicating an efficient transgenic expression of Mek1-EGFP in oligodendrocytes. Immunolabeling for phospho-ERK1/2 (Fig. 1A, bottom) showed increased cellular labeling intensity in the white matter of transgenic mice compared with the control.

To activate ERK1/2 in oligodendrocytes during adulthood after active myelination is largely terminated, we injected 2-month-old control, $\mathrm{PlpCre}{ }^{\mathrm{ERT}} ; \mathrm{Mek} /+$, and $\mathrm{PlpCre}{ }^{\mathrm{ERT}} ; \mathrm{Mek} /$ Mek mice intraperitoneally with Tm (100 $\mu \mathrm{g} / \mathrm{g}$ body weight) or the vehicle (sunflower oil) for 8 consecutive days. To validate that $\mathrm{Tm}$ injection achieved efficient Cre-mediated recombination and that the expression of Mek1-EGFP in mature oligodendrocytes occurred in a Mek1 gene dose-dependent manner, spinal cord sections were double labeled for EGFP and the oligodendrocyte marker CC1 (Fig. 1B, 2-month Tm injection). As expected, EGFP was not expressed in either sunflower-oil- or Tm-injected control mice or the sunflower-oil-injected $P l p C r e^{\text {ERT }} ; M e k /+$ and PlpCre ${ }^{\text {ERT }}$;Mek/Mek mice (data not shown). However, it was expressed in all regions of the spinal cord white matter in the Tminjected $\mathrm{PlpCre}{ }^{\mathrm{ERT}} ; \mathrm{Mek} /+$ and $\mathrm{PlpCre}{ }^{\mathrm{ERT}} ; \mathrm{Mek} / \mathrm{Mek}$ mice (Fig. $1 B$, ventral region). The EGFP expression overlapped with the majority of cells expressing $\mathrm{CC} 1$ and cell counts showed that $\sim 70 \%$ of $\mathrm{CC} 1+$ oligodendrocytes were also EGFP+. Further, the EGFP signal intensity was elevated incrementally in the $\mathrm{CC} 1+$ oligodendrocytes in the $\mathrm{PlpCre}{ }^{\mathrm{ERT}} ; \mathrm{Mek} /+$ and $\mathrm{PlpCre}{ }^{\mathrm{ERT}} ; \mathrm{Mek} / \mathrm{Mek}$ 


\section{A}
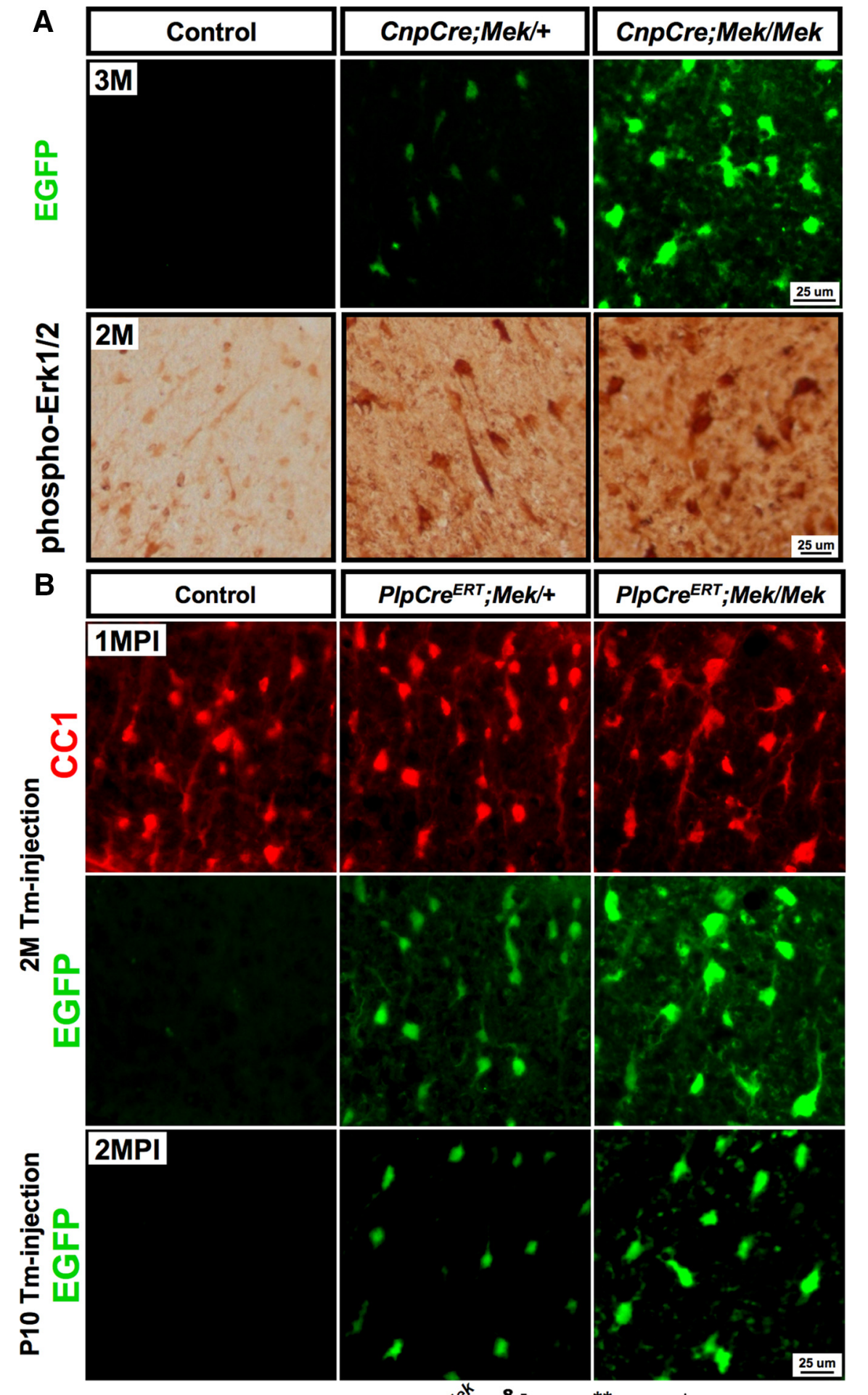

C
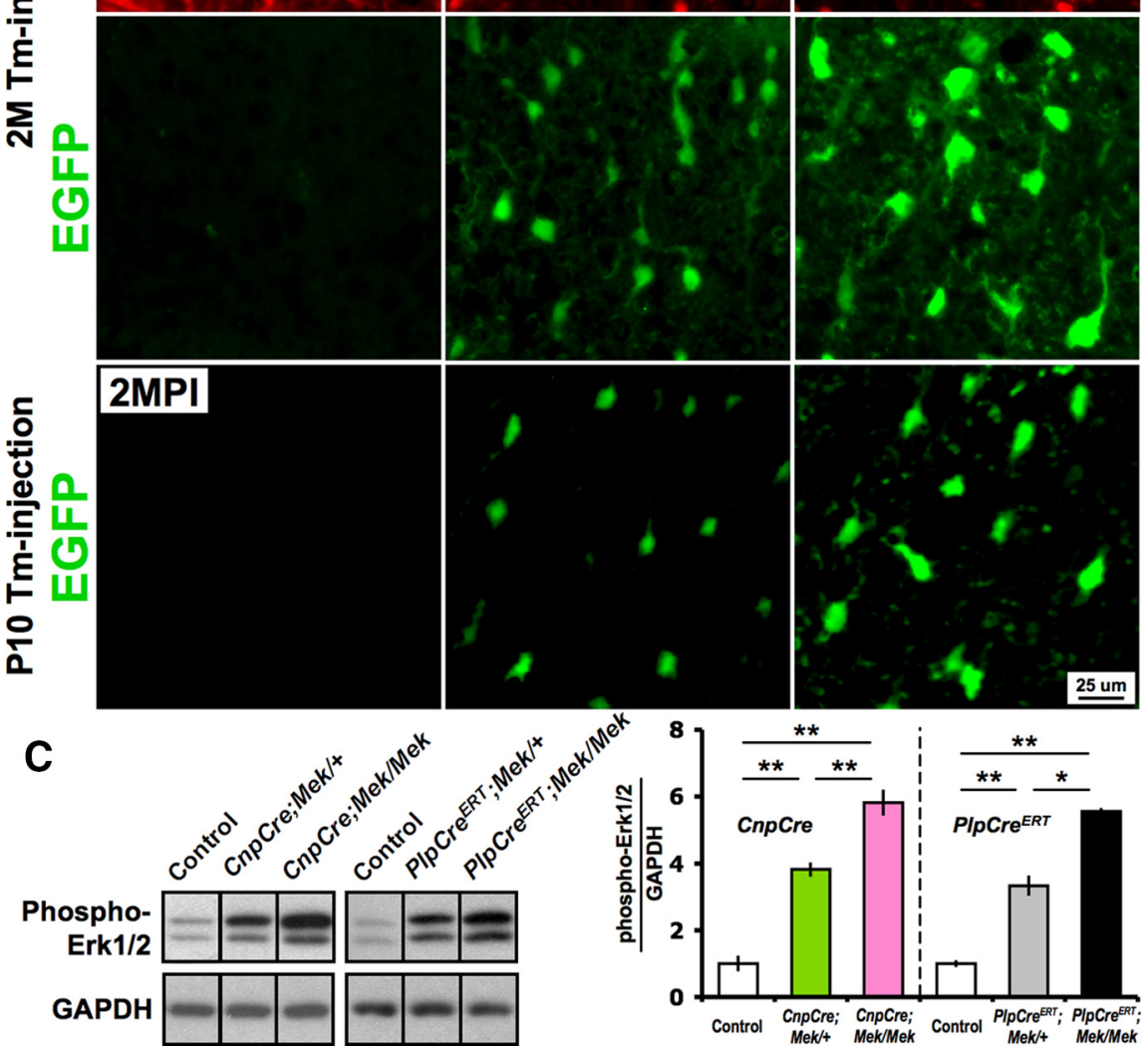

Figure 1. Increase in constitutively active Mek1 gene dosage in transgenic mice correlates with a graded increase in ERK1/2 activity and EGFP expression in oligodendrocytes. $\boldsymbol{A}$, Transverse sections of spinal cords from control, CnpCre; $M e k /+$, and CnpCre; Mek/Mek mice show graded EGFP signal intensity in the white matter of spinal cords of transgenic but not control mice (top). mice (Fig. $1 B$, middle). To activate ERK1/2 in oligodendrocytes during developmental myelination, Tm was injected to control, $\mathrm{PlpCre}^{\mathrm{ERT}} ; \mathrm{Mek} /+$, and $\mathrm{PlpCr}{ }^{\mathrm{ERT}} ; \mathrm{Mek} /$ Mek mice at P10 for 10 consecutive days (33 $\mu \mathrm{g} / \mathrm{g}$ body wt). Analysis of spinal cord sections showed that as expected, EGFP was not expressed in the controls but its signal intensity was incrementally elevated in the PlpCre ${ }^{\mathrm{ERT}} ; \mathrm{Mek} /+$ compared with the $P l p C r e^{\text {ERT }} ; M e k / M e k$ mice (Fig. $1 B, \mathrm{P} 10$ Tm injection).

Quantification of phospho-ERK1/2 levels by immunoblot analysis of white matter separated from the spinal cords of the control and transgenic mice further confirmed a statistically significant increase in ERK1/2 activity in CnpCre;Mek/Mek compared with the CnpCre;Mek/+ and control mice and PlpCre ${ }^{\mathrm{ERT}} ; \mathrm{Mek} / \mathrm{Mek}$ compared with the PlpCre ${ }^{\mathrm{ERT}} ; \mathrm{Mek} /+$ and control mice (Fig. 1C).

We conclude that ERK1/2 activation in oligodendrocytes was elevated incrementally with an increase of constitutively active Mek1 gene dosage in both lines of mice. Furthermore, Tm administration in $\mathrm{PlpCre}{ }^{\mathrm{ERT}} ; \mathrm{Mek} /+$ and $\mathrm{PlpCre}{ }^{\mathrm{ERT}}$;Mek/ Mek mice induced Cre-mediated recombination effectively in the majority of oligodendrocytes.

Incremental trend in myelin gene expression and size of oligodendrocytes upon graded upregulation of ERK1/2 activity

We investigated the effect of the graded increase of ERK1/2 activity on myelin gene expression in CnpCre;Mek/Mek mice compared with the CnpCre;Mek/+ mice at 3 months of age (Fig. 2A). In situ hybridization was performed simultaneously on all sections to allow overall comparisons between genotypes. We found that, compared with the controls,

$\longleftarrow$

Sections labeled for phospho-ERK1/2 (bottom) show increased cellular signal in the white matter of transgenic compared with control mice. $\boldsymbol{B}$, Control, PlpCre ${ }^{\mathrm{ERT}} ; \mathrm{Mek} /+$, and PIpCre ${ }^{\mathrm{ERT}}$;Mek/Mek mice were injected with tamoxifen either at 2 months or P10 for 8-10 d. Double immunolabeling for CC1 (red) and EGFP (green) at 1-2 MPI shows graded increase in EGFP expression in the spinal cords of PlpCre ${ }^{\mathrm{ERT}} ; \mathrm{Mek} /+$ and PIpCre ${ }^{\mathrm{ERT}}$;Mek/Mek mice. C, Immunoblot analysis for phospho-ERK1/2 in lysates of spinal cord white matter from CnpCre; Mek/+, CnpCre;Mek/Mek, and littermate control mice or from PlpCre ${ }^{\mathrm{ERT}} ; \mathrm{Mek} /+$, PlpCre ${ }^{\mathrm{ERT}} ;$ Mek/Mek, and littermate control mice showing a statistically significant increase in its expression in the Mek/Mek compared with the Mek/+ or control mice. GAPDH is used as a loading control. Error bars indicate SEM. ${ }^{*} p<0.05,{ }^{* *} p<0.01$, one-way ANOVA. $n=3$ for each condition. 

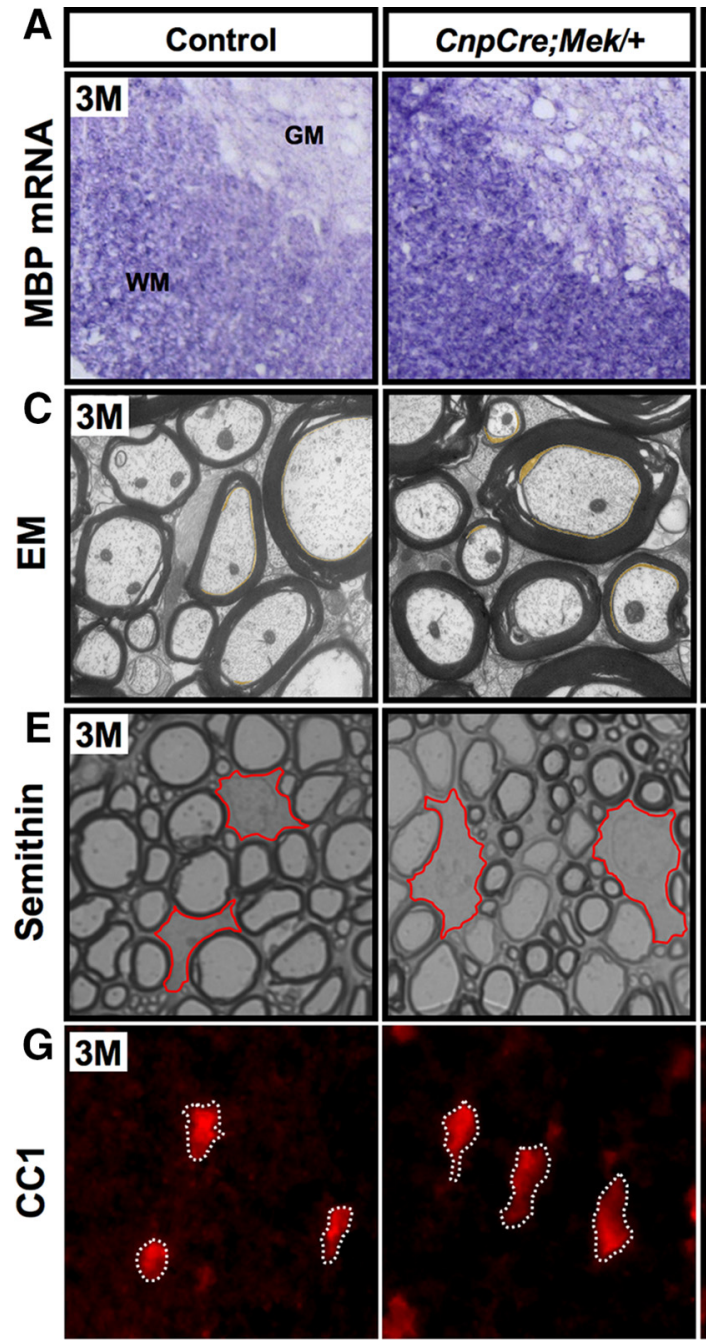

H

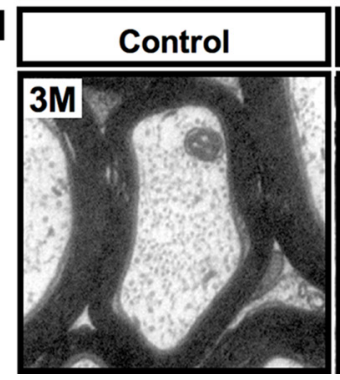

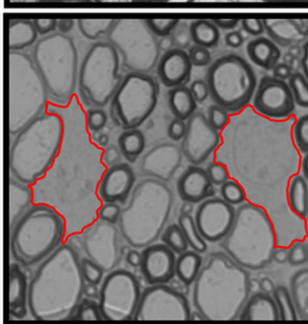
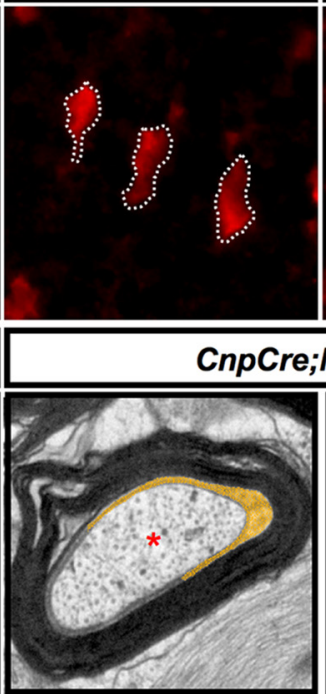
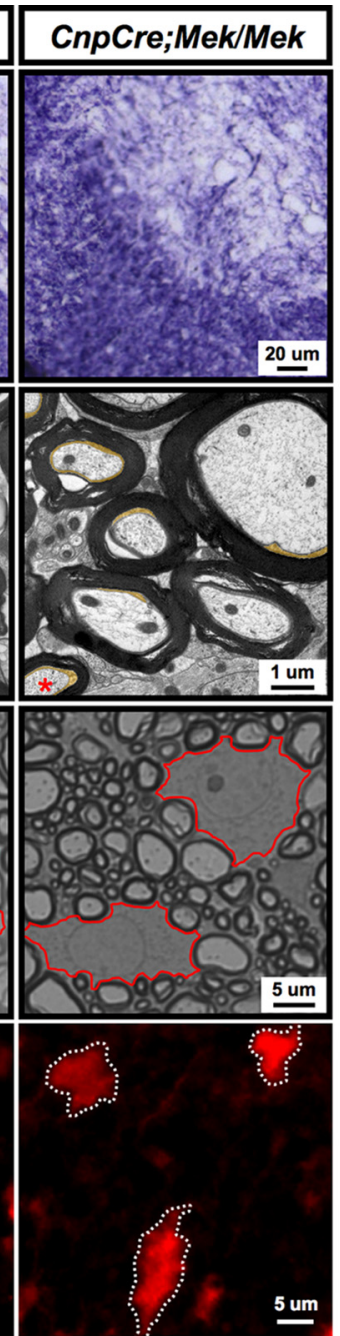

5 um
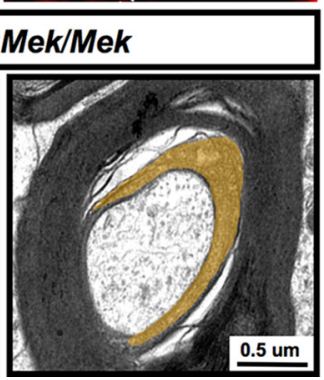

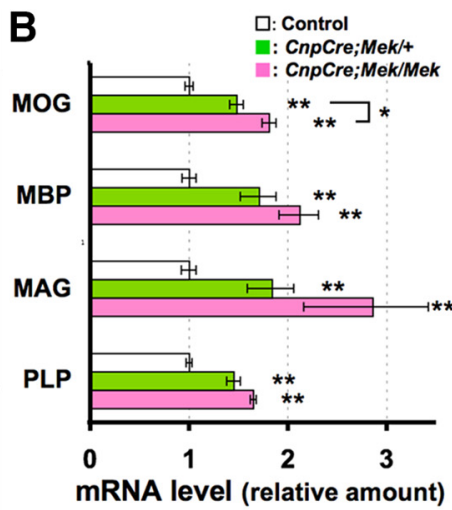

D

ㅁ. CnpCre;Mek/+

0.9 ]

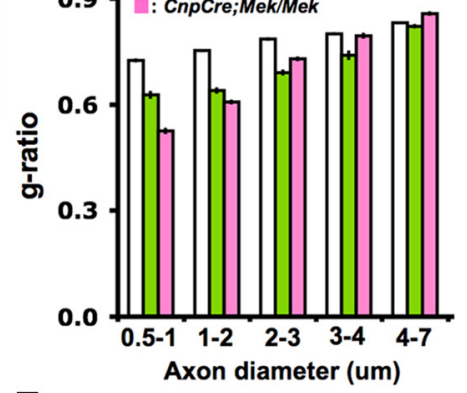

$F$

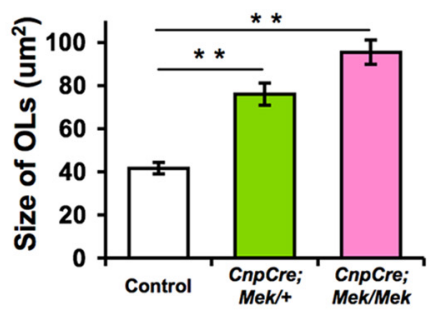

I

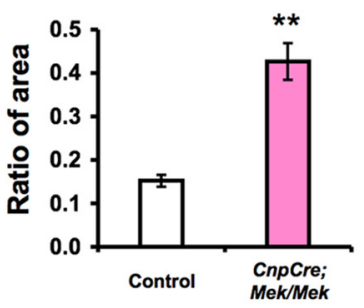

Figure 2. Incremental trend in myelin gene expression and size of oligodendrocytes upon graded upregulation of ERK1/2 activity. $\boldsymbol{A}$, Transverse sections of cervical spinal cord from control, CnpCre;Mek/+, and CnpCre;Mek/Mek mice analyzed at 3 months (M) by in situ hybridization for MBP mRNA expression show elevated signal intensity in the CnpCre;Mek/+ compared with control mice, which appeared to be further increased in the CnpCre;Mek/Mek mice. B, Quantification of mRNA levels for MOG, MBP, MAG, and PLP by qRT-PCR show a statistically significant increase of MOG and a trend toward an increase of other transcripts in the CnpCre;Mek/Mek compared with CnpCre;Mek/+ mice. Compared with controls, both the transgenics show statistically significant increases. Error bars indicate SEM. ${ }^{*} p<0.05,{ }^{* *} p<0.01 . n=3-6$ for each condition. $\boldsymbol{C}$, EM images of ventral cervical spinal cord sections from control, CnpCre;Mek/+, and CnpCre;Mek/Mek mice at 3 months show that the axons are wrapped by disproportionately thicker myelin sheaths in both the CnpCre;Mek/+ and CnpCre;Mek/Mek mice compared with controls. D, Quantification of myelin thickness by g-ratio analysis in matched regions of the ventral cervical spinal cord confirmed the relative increase in myelin thickness (lower g-ratios) in both the C $n p(r e ; M e k /+$ and CnpCre;Mek/Mek mice compared with littermate controls (average g-ratios of axons between 0.5 and $3 \mu \mathrm{m}$ : control, $0.752 \pm 0.003 ;$ CnpCre;Mek/,$+ 0.644 \pm 0.006 ;$ CnpCre;Mek/Mek, $0.607 \pm 0.007, p=0.42 \times 10^{-46}$ and $p=0.3 \times 10^{-66}$, respectively; $\sim 140$ axons were analyzed from at least 2 mice per group). Comparison of $\left(n p\left(r e ; M e k /+\right.\right.$ and $\left(n p\left(r e ; M e k / M e k\right.\right.$ mice show significant differences only for axons between 0.5 and $1 \mu \mathrm{m}\left(p=1.5 \times 10^{-10}\right) ;$ other differences in g-ratios are not statistically significant. $\boldsymbol{E}, \boldsymbol{F}$, Toulidine-blue-stained semithin sections of cervical spinal cords from 3-month-old mice show a trend toward an increase in the size of oligodendrocytes ( $\mathrm{LLS}$ ) in the CnpCre;Mek/Mek compared with CnpCre;Mek/+ mice (outlined in red). Compared with controls, both the transgenic mice show statistically significant increases in the size of $0 \mathrm{~L}$ cell bodies. Areas $\left(\mu \mathrm{m}^{2}\right)$ of at least 60 cell bodies was measured per group from at least 2 mice per group. $\mathbf{G}$, Anti-CC1-immunolabeled transverse sections also show this trend. $\boldsymbol{H}$, EM images of the spinal cord of control and CnpCre;Mek/Mek mice show enlarged cytoplasmic inner tongue and associated periaxonal collar of myelin (colored). The axon identified by red asterisks in $\mathbf{C}$ is shown at higher magnification in $\boldsymbol{H}$. I, Quantification of the relative area of the cytoplasmic inner tongue with associated periaxonal collar and the area of the axon (ratio of area) shows that the increase in CnpCre;Mek/Mek is statistically significant compared with control mice. Approximately 145 axons were analyzed per group from at least two mice per group. Error bars indicate SEM. ${ }^{* *} p<0.01$. WM, White matter; GM, gray matter. 
there was an increase in the intensity of MBP mRNA signal in the CnpCre;Mek/+ mice, which appeared to be further increased in the CnpCre;Mek/Mek mice. Quantification of the mRNA levels of major myelin genes (MBP, MOG, MAG, and PLP) by qRT-PCR showed that, in all cases, there was an increase of $\sim 20-50 \%$ in the CnpCre;Mek/Mek compared with the CnpCre;Mek/+ mice, showing a trend toward an elevation with increased ERK1/2 activity, although statistical significance was reached only for MOG. However, compared with controls, both CnpCre;Mek/+ and $\mathrm{CnpCre;Mek/Mek}$ mice showed a statistically significant increase (Fig. $2 B$ ).

To determine whether graded elevation of ERK1/2 in CnpCre; Mek/+ and CnpCre;Mek/Mek mice affected the numbers of differentiated oligodendrocytes, we performed in situ hybridization for PLP mRNA to identify and quantify mature oligodendrocytes in the whole lateroventral white matter of the spinal cords at 3 months of age. We found that, compared with controls, there was no statistically significant change in the numbers of oligodendrocytes in the CnpCre;Mek/Mek or CnpCre;Mek/+ mice (control = $994 \pm 84 ;$ CnpCre;Mek/+= $824 \pm 74 ;$ CnpCre;Mek/Mek = $1075 \pm 33 ; \mathrm{N}=3$ ). Therefore, the increase in PLP mRNA (above) must be due to an increase per oligodendrocyte. A similar increase in PLP mRNA per oligodendrocyte was also observed previously in CnpCre;Mek/+ during developmental myelination (Ishii et al., 2013).

To determine the effect of ERK1/2 elevation on myelin thickness and ultrastructure of myelinated fibers, ventral cervical spinal cord sections from control, CnpCre;Mek/+, and CnpCre; Mek/Mek mice were examined at 3 months of age by EM analysis (Fig. 2C). The micrographs showed that the axons were wrapped by disproportionately thicker myelin sheaths in both the CnpCre; Mek/+ and CnpCre;Mek/Mek mice compared with controls. Morphometric quantification of myelin thickness by g-ratio analysis (ratio of individual axon diameters to myelinated fiber diameters) in matched regions of the ventral cervical spinal cord confirmed the relative increase in myelin thickness (lower g-ratios; Fig. 2D). When CnpCre;Mek/+ and CnpCre;Mek/Mek mice were compared with littermate controls the most significant differences were observed for axons ranging between 0.5 and 3 $\mu \mathrm{m}$ (average g-ratios: control, $0.752 \pm 0.003$; CnpCre;Mek/+, $0.644 \pm$ 0.006; CnpCre;Mek/Mek, $0.607 \pm 0.007, p=0.42 \times$ $10^{-46}$ and $p=0.3 \times 10^{-66}$, respectively; $\sim 140$ axons were analyzed from at least two mice per genotype). However when CnpCre;Mek/+ were compared with CnpCre;Mek/Mek mice, the most significant differences were seen only for axons between 0.5 and $1 \mu \mathrm{m}\left(p=1.5 \times 10^{-10}\right)$. The $p$-values for other subgroups were lower and therefore were considered to show no significant decreases or increases in myelin thickness. Therefore, a general correlation of Mek1 gene dosage with myelin thickness for all diameter fibers could not be made.

Examination of semithin sections from the spinal cords of 3-month-old control and CnpCre;Mek/+ mice showed oligodendrocyte hypertrophy in the CnpCre;Mek/+ mice, similar to that reported recently (Fyffe-Maricich et al., 2013). Quantification showed that, compared with control, there were statistically significant increases in the sizes of oligodendrocytes in both CnpCre; Mek/+ and CnpCre;Mek/Mek mice. Increasing the level of ERK1/2 activation in the CnpCre;Mek/Mek mice showed a trend toward a further increase compared with the CnpCre;Mek/+ mice, but did not reach statistical significance (Fig. 2 E, F). Oligodendrocytes identified by CC1 immunolabeling in the spinal cords of these mice also showed this trend of increase in their sizes (Fig. 2G).
Another interesting phenotype observed by EM analysis of spinal cords from 3-month-old CnpCre;Mek/Mek and, to a lesser extent, CnpCre;Mek/+ mice was that, compared with control, there was a striking enlargement of the cytoplasmic inner tongue and associated periaxonal collar of myelin that is consistent with new myelin growth (Fig. $2 H$ ). Quantification of the sizes of these enlargements showed a statistically significant increase compared with controls (Fig. 2I).

We conclude that, because the levels of several major myelin genes show a clear trend toward an increase in the Mek/Mek compared with the Mek/+ mice, it is likely that the strength of ERK1/2 activation may have an impact on myelin gene expression in oligodendrocytes. However, because, quantitatively, not all increases reached statistical significance, it precludes us from unequivocally correlating the two. Furthermore, a general correlation of Mek gene dosage to myelin thickness could not be made because statistically significant increases were not reached for all diameter fibers. It is possible that a more robust dose-dependent increase could not be seen because the positive influence of increased ERK1/2 activation was partly negated when ERK1/2 were hyperactivated (see below).

\section{Elevation of ERK1/2 activity during adulthood reactivates quiescent mature oligodendrocytes to upregulate myelin gene expression and reinitiate active myelin growth}

After developmental myelination, active myelin growth slows down dramatically during adulthood and the levels of ERK1/2 and major myelin genes are downregulated to a basal level. Given our finding suggesting a role of ERK1/2 in the regulation of myelin gene expression during active myelination in vivo (Ishii et al., 2012), we investigated whether elevation of ERK1/2 activity in mature oligodendrocytes in adulthood could potentially "reawaken" the normally downregulated myelin gene expression and reinitiate myelin growth. We therefore analyzed the levels of myelin gene expression in the control, $\mathrm{PlpCre}{ }^{\mathrm{ERT}} ; \mathrm{Mek} /+$, and PlpCre ${ }^{\mathrm{ERT}}$;Mek/Mek mice, in which ERK1/2 were overstimulated incrementally after Tm injections specifically in adulthood (2 months), after adult myelin structure is largely established (Fig. 3). In situ hybridization was performed simultaneously on spinal cord sections at 3,6, and 8 months postinjection (MPI) (3 MPI is shown in Fig. $3 A$ ). We found that, compared with controls, there was an increase in the intensity of MBP mRNA signal in both the PlpCre ${ }^{\mathrm{ERT}} ; \mathrm{Mek} /+$ and $\mathrm{PlpCr}{ }^{\mathrm{ERT}} ; \mathrm{Mek} / \mathrm{Mek}$ mice. Consistent with these observations, the quantification of mRNA levels by qRT-PCR showed an elevation of MBP transcripts in both the transgenic mice compared with control mice at all 3 ages (Fig. $3 B$ ). PLP mRNA expression also showed an increase in gene expression in the transgenic mice compared with control mice at each of the time points (Fig. 3C).

To determine the effect of ERK1/2 elevation on reinitiation of myelin growth, we next examined myelin thickness in the ventral cervical spinal cord sections from control and $\mathrm{PlpCre}{ }^{\mathrm{ERT}} ; \mathrm{Mek} /+$ adult mice using EM analysis (Fig. $3 D, E$ ). Morphometric quantification of myelin thickness by g-ratio analysis in matched regions of the ventral cervical spinal cord at 6 MPI showed that, compared with control, there was an increase in myelin thickness (lower g-ratios) in the $\mathrm{PlpCr}{ }^{\mathrm{ERT}} ; \mathrm{Mek} /+$ mice (average g-ratios: control, $0.74 \pm 0.003 ; \mathrm{PlpCre}{ }^{\mathrm{ERT}} ; \mathrm{Mek} /+, 0.68 \pm 0.004, p=$ $4.29 \times 10^{-26} ; \sim 500$ axons were analyzed from at least two mice per group).

To investigate whether ERK1/2 activation in adult oligodendrocytes could reinitiate myelin growth in other regions of the CNS, we examined optic nerves of $P l p C r e^{\mathrm{ERT}} ; M e k /+$ and littermate control 


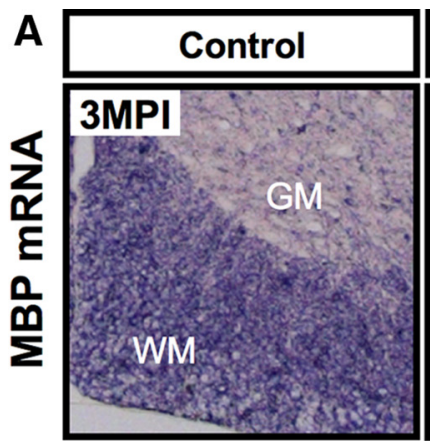

B
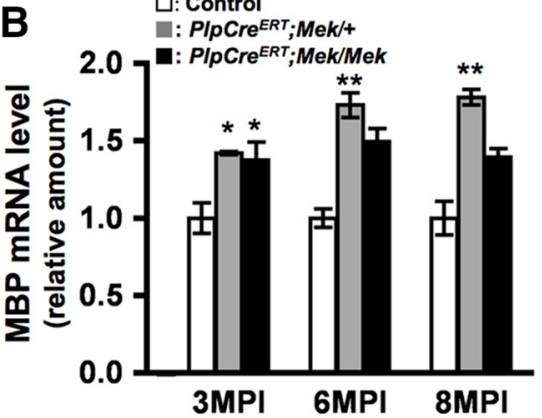

C

C

\section{口: Control}

: PlpCre ${ }^{E R T} ; M e k /+$

: PlpCre ${ }^{E R T} ; M e k / M e k$

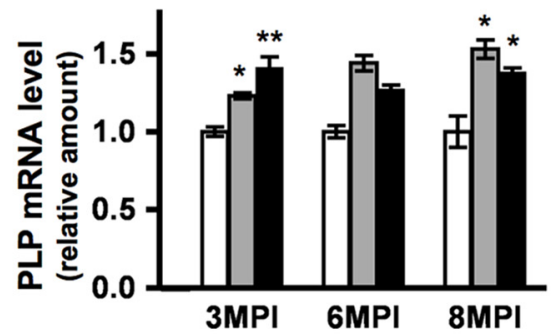

D
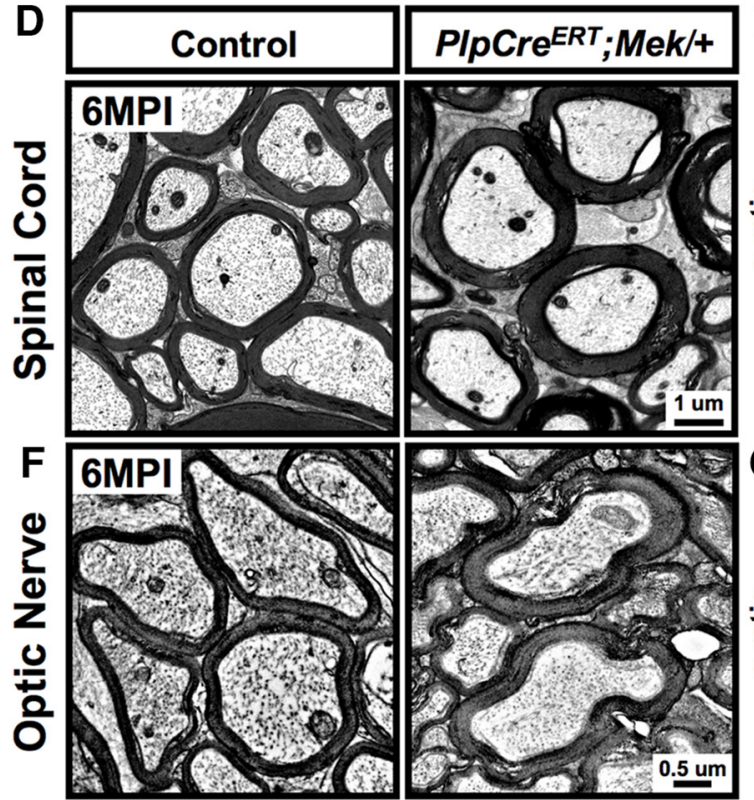

$\mathbf{H}$
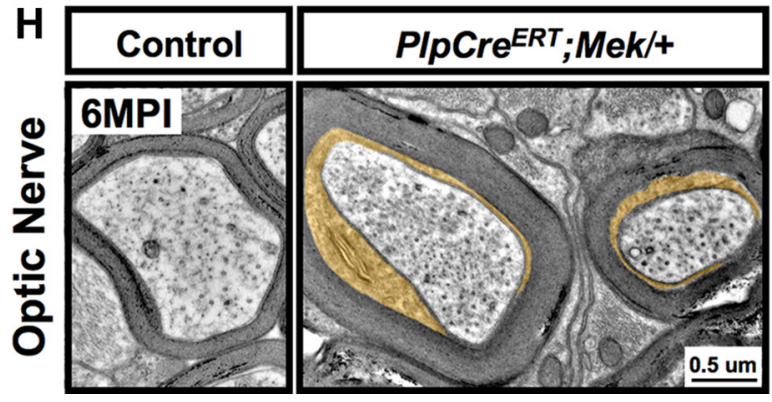

E

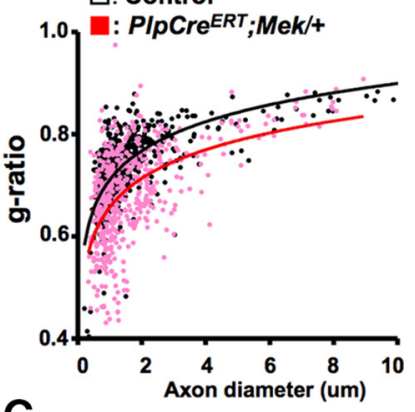

G

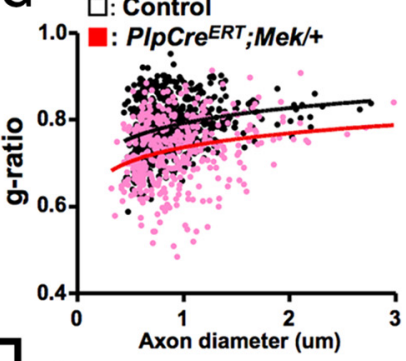

I

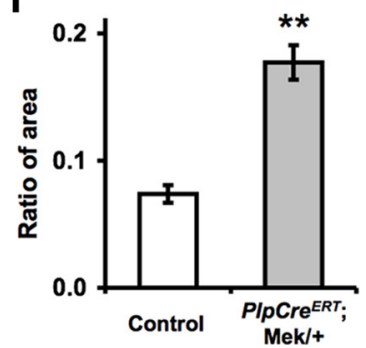

Figure 3. Elevation of ERK1/2 activity during adulthood can reactivate quiescent mature oligodendrocytes to upregulate myelin gene expression and myelin growth. $\boldsymbol{A}$, Control, $P l p C r e^{\mathrm{ERT}} ; \mathrm{Mek} /+$, and $P l p C r e^{\mathrm{ERT}} ; \mathrm{Mek} / \mathrm{Mek}$ mice injected with tamoxifen at 2 months of age, analyzed at $3 \mathrm{MPI}$ by in situ hybridization, show that the signal intensity of MBP $m$ RNA expression is increased in the spinal cords of PlpCre ${ }^{\mathrm{ERT}} ;$ Mek/ + and PIpCre ${ }^{\mathrm{ERT}} ;$;Mek/Mek mice compared with littermate controls. B, C, Quantification of MBP and PLP mRNA levels by qRT-PCR at 3, 6, and 8 MPI shows a significant increase in their levels in both PIpCre ${ }^{\text {ERT }}$; Mek/+ and PIpCre ${ }^{\text {ERT; }}$; Mek/Mek mice compared with controls at all time points. Control values are normalized to 1. Error bars indicate SEM. ${ }^{*} p<0.05$, ${ }^{* *} p<0.01 . n=3-4$ for each condition. WM, White matter; GM, gray matter. $\boldsymbol{D}, E, E M$ images and quantification of myelin thickness by g-ratio analysis (scatter plot) in ventral cervical spinal cord sections from control and $P / p C r e{ }^{\text {ERT }} ; M e k /+$ mice at $6 \mathrm{MP}$

mice at 6 MPI using EM analysis (Fig. $3 F, G)$. An increase in myelin thickness quantified by g-ratio analysis was observed in the optic nerves of these mice, similar to that seen in the spinal cords (average g-ratios: control, $0.78 \pm 0.002 ;$ PlpCre $e^{\mathrm{ERT}}$; $\mathrm{Mek} /+, 0.73 \pm 0.004, p=0.19 \times 10^{-10}$ 599 control and 397 PlpCre ${ }^{\mathrm{ERT}} ; \mathrm{Mek} /+$ axons were analyzed from at least 2 mice per group). Enlargement of the cytoplasmic inner tongue and associated enlargement of periaxonal collar of myelin, consistent with new myelin growth (Snaidero et al., 2014), were observed in the $\mathrm{PlpCre}{ }^{\mathrm{ERT}} ; \mathrm{Mek} /+$ mice (Fig. $3 H$, colored). Quantification of the sizes of these enlargements showed a statistically significant increase compared with controls (Fig. 3I). Numerous axons with thick myelin sheaths and enlarged periaxonal collars were also observed in $\mathrm{PlpCre}{ }^{\mathrm{ERT}}$;Mek/Mek mice (data not shown).

From these data, together with the observation that the number of mature oligodendrocytes remained unchanged in the

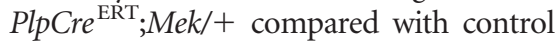
mice (see below), we conclude that even moderate elevation of ERK1/2 activity during adulthood upregulates myelin gene expression and reinitiates new myelin growth in the adult CNS from preexisting oligodendrocytes.

ERK1/2 overactivation upregulates mTOR in oligodendrocytes of the adult CNS

Given the similarities that we observed in the phenotypes of transgenic mice with overstimulation of the ERK1/2-MAPK and PI3K/Akt/mTOR pathways, such as increased size of oligodendrocytes and reinitiation of myelin growth during adult-

show a relative increase in myelin thickness (lower g-ratios) in the PIpCre ${ }^{\mathrm{ERT}} ; \mathrm{Mek} /+$ compared with littermate controls (average g-ratios: control, $0.74 \pm 0.003 ;$ Plp $\left(r^{\text {ERT }} ; M e k /+\right.$, $0.68 \pm 0.004, p=4.29 \times 10^{-26} ; \sim 500$ axons were analyzed per genotype from at least 2 mice in each group). $\boldsymbol{F}, \boldsymbol{G}$, EM images and quantification of myelin thickness by $g$-ratio analysis (scatter plot) in optic nerve sections from control and PlpCre ${ }^{\mathrm{ERT}}{ }_{;} \mathrm{Mek} /+$ mice at $6 \mathrm{MPI}$ show an increase in myelin thickness (lower g-ratios) in the Plp(re ${ }^{\mathrm{ERT}} ; M e k /+$ compared with littermate controls (average g-ratios: control, $0.78 \pm$ $0.002 ;$ PlpCre $^{\text {ERT }} ;$ Mek $/+, 0.73 \pm 0.004, p=0.19 \times 10^{-10}$; $\sim 500$ axons were analyzed from at least two mice per group). $\boldsymbol{H}$, EM images from optic nerves show enlarged cytoplasmic inner tongue and associated periaxonal collar of myelin (colored) in Plp(re ${ }^{\mathrm{ERT}} ;$ Mek/+ compared with control mice. I, Quantification of the relative area of the cytoplasmic inner tongue with associated periaxonal collar and the area of the axon, (ratio of area) shows that the increase is staistically significant. Approximately 85 axons per group from at least two mice per group were analyzed. Error bars indicate SEM. ${ }^{* *} p<$ 0.01 . 


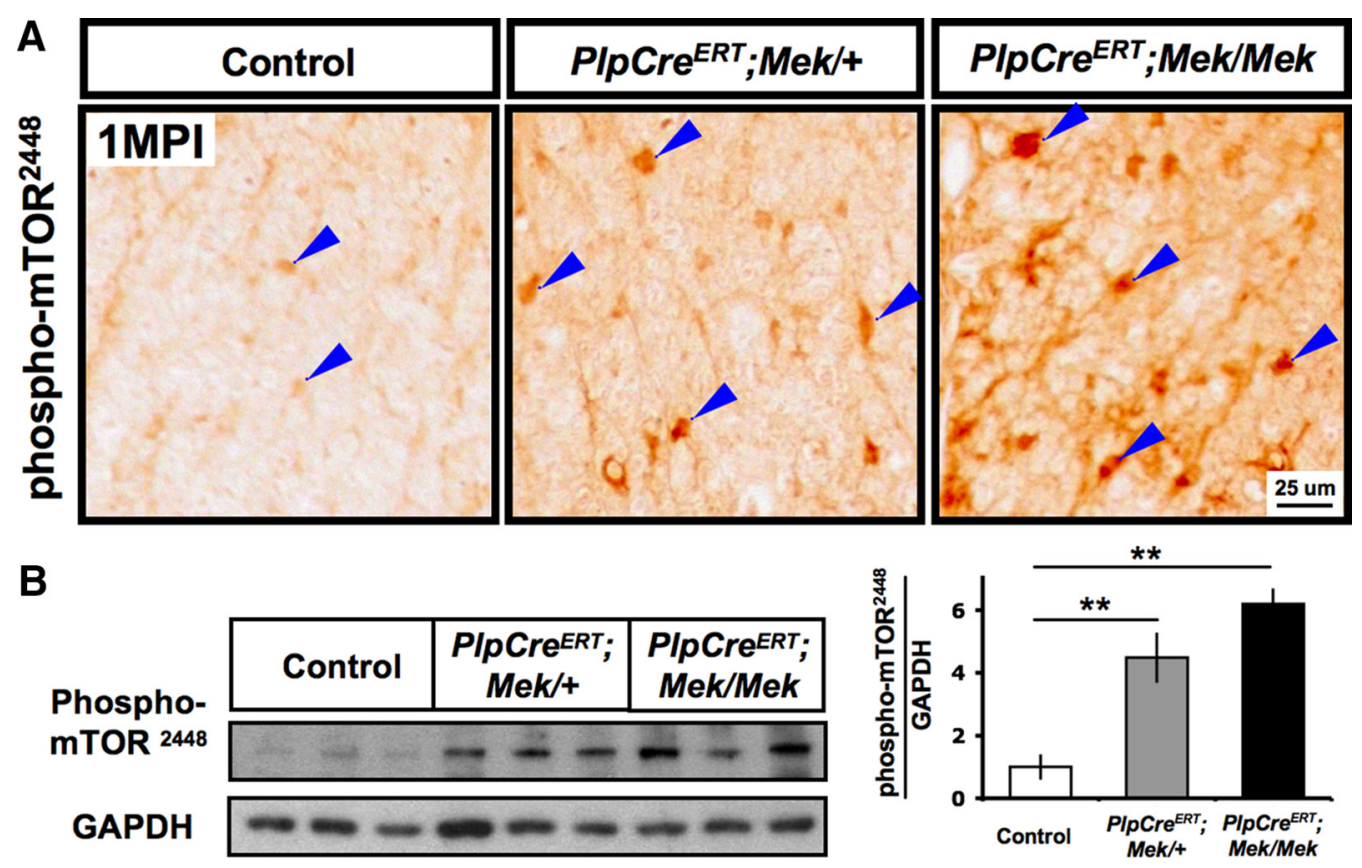

Figure 4. ERK1/2 overactivation upregulates phospho-mTOR in oligodendrocytes of the adult CNS. A, Spinal cord sections from control, PlpCre ${ }^{\text {ERT; }}$ Mek/+, and PlpCre ${ }^{\text {ERT }}$;Mek/Mek mice injected with tamoxifen at 2 months and analyzed at $1 \mathrm{MPI}$ by immunolabeling for phospho-mTOR ${ }^{2448}$ show that the intensity of cellular staining in the white matter increases in the PlpCre ${ }^{\mathrm{ERT}} ; M e k /+$ and $P I p C r e^{\mathrm{ERT}} ;$ Mek/Mek compared with control mice. Representative images from the analysis of three animals per genotype are shown. Arrowheads point to phospho-mTOR+ cell bodies $\boldsymbol{B}$, Immunoblot analysis for phospho-mTOR ${ }^{2448}$ in lysates of spinal cords white matter from control, PlpCre ${ }^{\text {ERT }}$;Mek/+, and PIpCre ${ }^{\text {ERT; }}$;Mek/Mek mice show statistically significant increases in its expression in both the PIpCre ${ }^{\mathrm{ERT}} ;$ Mek/+ and PIpCre ${ }^{\mathrm{ERT}} ;$ Mek/Mek mice compared with controls and a trend toward an increase in the PlpCre ${ }^{\mathrm{ERT}} ;$ Mek/Mek compared with PlpCre ${ }^{\mathrm{ERT}} ;$ Mek/+ mice. GAPDH is shown as the loading control. Error bars indicate SEM. ${ }^{* *} p<0.01$, one-way ANOVA. $n=3$ for each condition.

hood (Goebbels et al., 2010; Snaidero et al., 2014), we next investigated whether overstimulation of ERK1/2 in mature oligodendrocytes would have an impact on the expression of mTOR (Fig. 4). Spinal cord sections from control, PlpCre ${ }^{\text {ERT }} ; \mathrm{Mek} /+$, and $\mathrm{PlpCre}{ }^{\mathrm{ERT}} ; \mathrm{Mek} / \mathrm{Mek}$ mice were immunolabeled for phospho-mTOR at $1 \mathrm{MPI}$. Weak cellular staining of phosphomTOR was observed in the white matter of control mice, as is expected by this age. However, a clear increase in the intensity of the signal was observed in both transgenic mice compared with the controls. The signal was slightly higher in the homozygotes relative to heterozygotes (Fig. 4A). Quantification of phosphomTOR levels by immunoblot analysis of white matter separated from the spinal cords of the control and transgenic mice further showed that compared with controls there was a statistically significant increase in phospho-mTOR levels in both $P l p C r e^{\text {ERT }}$; Mek/+ and PlpCre ${ }^{\mathrm{ERT}} ; \mathrm{Mek} / \mathrm{Mek}$ mice. A trend toward an increase was also observed in the $P l p C r e^{\text {ERT }} ; M e k / M e k$ compared with $P l p C r e^{\mathrm{ERT}} ; M e k /+$ mice, but did not reach statistical significance (Fig. 4B).

We conclude that mTOR activity is upregulated in the quiescent oligodendrocytes of the adult CNS by overactivation of ERK1/2.

Progressive motor function impairment is caused at later ages in the $\mathrm{Pl} p \mathrm{Cre}^{\mathrm{ERT}} ; \mathrm{Mek} / \mathrm{Mek}$, but not $\mathrm{PlpCre}{ }^{\mathrm{ERT}} ; \mathrm{Mek} /+$, mice The motor function of both the PlpCre ${ }^{\text {ERT }} ; M e k /+$ and PlpCre ${ }^{\text {ERT}}$;Mek/Mek mice appeared normal up to $\sim 3$ MPI. However, by $\sim 6 \mathrm{MPI}$, the PlpCre ${ }^{\mathrm{ERT}}$;Mek/Mek mice began to display obvious motor deficits. Therefore, we analyzed control, PlpCre${ }^{\mathrm{ERT}} ; \mathrm{Mek} /+$, and $\mathrm{PlpCre}{ }^{\mathrm{ERT}} ; \mathrm{Mek} / \mathrm{Mek}$ mice to quantify potential defects in neuromotor coordination and strength by the rotarod (Fig. 5A) and wire-hanging tests (Fig. 5B). At 2-3 MPI, the control and both transgenic mice were able to stay on the rotating rod or inverted wire grid for the same amount of time before falling. However, at $6 \mathrm{MPI}$, the $\mathrm{PlpCre}{ }^{\mathrm{ERT}} ; \mathrm{Mek} / \mathrm{Mek}$ mice fell significantly more rapidly than the $\mathrm{PlpCr} \mathrm{ERT}^{\mathrm{ERT}} \mathrm{Mek} /+$ or control mice in both of the tests. These defects became progressively worse by 8 MPI. The impairment of motor function was accompanied by a visible clinical defect in the gait of the $\mathrm{PlpCre}{ }^{\mathrm{ERT}} ; \mathrm{Mek} / \mathrm{Mek}$ mice. Specifically, the hind limbs appeared to drag as the mutant mice walked. To further document this defect in gait, we dipped the

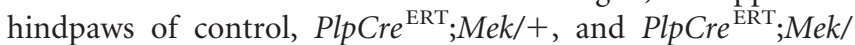
Mek mice in paint and examined their footprints as they walked on paper (Fig. 5C). Although the paw imprints of the control and PlpCre ${ }^{\mathrm{ERT}} ; \mathrm{Mek} /+$ mice indicated normal gait, those of the PlpCre ${ }^{\text {ERT }}$;Mek/Mek mice indicated a dragging motion of their hind feet. We conclude that hyperactivation of ERK1/2 activity in adult oligodendrocytes of the $\mathrm{PlpCr}{ }^{\mathrm{ERT}} ; \mathrm{Mek} / \mathrm{Mek}$ mice gives rise to progressive impairment of their motor functions at later ages.

Increasing the strength of ERK1/2 activation in oligodendrocytes results in myelin and axonal pathology at higher dose (Mek/Mek) but not at lower dose (Mek/+) regardless of the timing of its activation Given the observed motor deficits in the $\mathrm{PlpCre}{ }^{\mathrm{ERT}} ; \mathrm{Mek} / \mathrm{Mek}$ mice, we examined myelin ultrastructure in the $P l p C r e^{\mathrm{ERT}}$; $\mathrm{Mek} /+$ and $\mathrm{PlpCre}{ }^{\mathrm{ERT}} ; \mathrm{Mek} / \mathrm{Mek}$ mice for potential myelin and axonal defects. Toluidine-stained semithin sections and EM images of spinal cord ventral-lateral white matter from $P l p C r e^{\text {ERT}}$; $\mathrm{Mek} /+$ and $\mathrm{PlpCre}{ }^{\mathrm{ERT}} ; \mathrm{Mek} / \mathrm{Mek}$ mice injected with $\mathrm{Tm}$ at 2 months of age and analyzed at 3, 6, and 8 MPI revealed significant myelin and axonal deficits in Tm-injected PlpCre ${ }^{\mathrm{ERT}} ; \mathrm{Mek} / \mathrm{Mek}$, but not PlpCre ${ }^{\mathrm{ERT}} ; \mathrm{Mek} /+$ or control mice (Fig. 6A, 3 and 8 MPI are shown). These include widespread demyelination and axonal degeneration, indicated by the presence of abnormal myelin figures such as darkly stained ovals and empty spaces surrounded by 
A

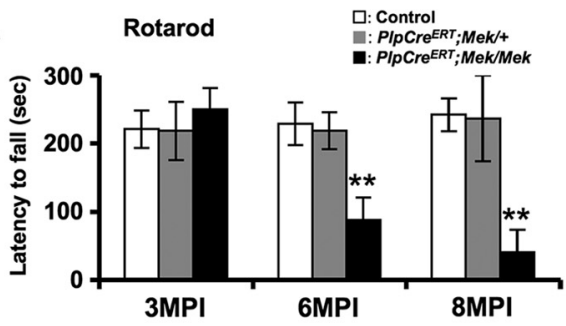

B
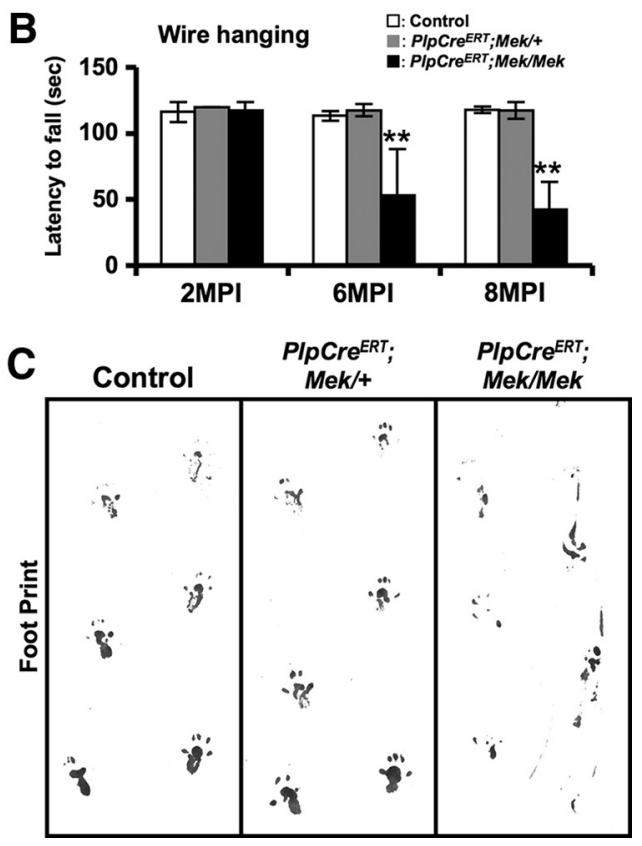

Figure 5. Progressive motor function impairment is caused at later ages in the PlpCre ${ }^{\text {ERT, }}$ Mek/Mek mice, but not in the PlpCre ${ }^{\text {ERT }} ; \mathrm{Mek} /+$ mice. Rotarod $(\boldsymbol{A})$ and wire-hanging $(\boldsymbol{B})$ tests performed at 2-3, 6, and 8 MPI show that PIpCre ${ }^{\mathrm{ERT}} ;$ Mek/Mek, but not PIpCre ${ }^{\mathrm{ERT}}$; Mek/+, mice display a progressive reduction in the latency to fall. $\boldsymbol{C}$, Imprints of hindpaws taken at $6 \mathrm{MPI}$ show that, whereas the control and PIpCre ${ }^{\mathrm{ERT}} ; M e k /+$ mice have a normal gait, the PIpCre ${ }^{\mathrm{ERT}}$; Mek/Mek mice show a dragging motion of their hind feet. Error bars indicate SEM. ${ }^{* *} p<0.01$. $n=4-9$.

thin myelin (Fig. 6A, arrowheads, asterisk). High-magnification EM images of spinal cords from $\mathrm{PlpCre}{ }^{\mathrm{ERT}} ; \mathrm{Mek} / \mathrm{Mek}$ mice showed these defects more clearly, including: (1) unmyelinated and thinly myelinated axons indicative of ongoing demyelination and remyelination, (2) a degenerated axon with degenerating myelin, and (3) a degenerating axon with an unraveling, deteriorating myelin sheath. These abnormalities were observed in the white matter of the spinal cords from as early as $3 \mathrm{MPI}$, becoming progressively worse at 6 and $8 \mathrm{MPI}$. Consistent with the EM images, quantification of these darkly stained ovals at $3 \mathrm{MPI}$ showed a statistically significant increase in $\mathrm{PlpCre}{ }^{\mathrm{ERT}} ; \mathrm{Mek} / \mathrm{Mek}$ compared with $\mathrm{PlpCre}{ }^{\mathrm{ERT}} ; \mathrm{Mek} /+$ or control mice (Fig. 6B). Further, quantification of myelinated and unmyelinated axons showed that there were significantly more unmyelinated axons in the spinal cords of $P l p C r e^{\mathrm{ERT}} ; \mathrm{Mek} / \mathrm{Mek}$ mice $(\sim 31 \%)$ compared with controls and PlpCre ${ }^{\mathrm{ERT}} ; \mathrm{Mek} /+$ mice $(\sim 9 \%)$ and that myelinated axons were significantly lower (Fig. 6C).

It is possible that myelin and axonal pathology in the $\mathrm{PlpCre}^{\mathrm{ERT}}$;Mek/Mek mice injected with Tm at 2 months could have been triggered by untimely strong reactivation of ERK $1 / 2$ in quiescent oligodendrocytes after myelination has been largely terminated. We therefore next investigated whether the commencement of ERK1/2 elevation beginning earlier-that is, dur- ing developmental myelination-would also lead to a similar pathology during adulthood. We therefore injected Tm at P10 to induce conditionally the activation of constitutively active Mek1 earlier and examined semithin toluidine-stained sections and EM images from spinal cords of control, $\mathrm{PlpCre}{ }^{\mathrm{ERT}} ; \mathrm{Mek} /+$, and PlpCre ${ }^{\text {ERT }}$;Mek/Mek mice (Fig. 6D). Similar to the 2-month Tm-injected mice, the P10 Tm-injected PlpCre ${ }^{\text {ERT }} ; M e k / M e k$ mice also displayed clear signs of myelin and axonal pathology at 8 MPI. As shown in Figure 6, $D a-D c$, degenerating myelinated axons at various stages of deterioration were prevalent. Figure 6Da displays a myelinated profile that lacks an axon most likely as a result of axonal fallout. The adjacent myelin profile exhibits an axon that displays degenerating organelles and is highly vacuolated consistent with an earlier stage of axonal fallout. Figure 6, $D b$ and $D c$, present additional examples of persistent myelin profiles that lack axons consistent with axonal degeneration. In contrast to the homozygous PlpCre ${ }^{\text {ERT }} ; \mathrm{Mek} / \mathrm{Mek}$ mice, the heterozygous $\mathrm{PlpCre}{ }^{\mathrm{ERT}} ; \mathrm{Mek} /+$ mice did not show any myelin/ axonal pathology at this age. We also examined the CnpCre; Mek/+ and CnpCre;Mek/Mek mice at 4 months of age and obtained similar results (data not shown).

We conclude from these data that, regardless of the time when graded ERK1/2 elevation first commences, myelin and axonal pathology occurred at higher doses $(M e k / M e k)$, but not at lower doses $(M e k /+)$.

Viability of oligodendrocytes is partially affected at later ages

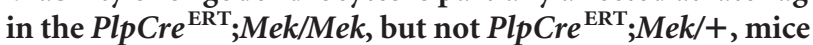
Given the observed demyelination in the $P l p C r e^{\mathrm{ERT}} ; \mathrm{Mek} / \mathrm{Mek}$ mice, we next investigated whether the viability of the oligodendrocytes was affected in these animals compared with the $P l p C r e^{\text {ERT }} ; M e k /+$ mice. Spinal cord sections from control, Plp$\mathrm{Cre}^{\mathrm{ERT}} ; \mathrm{Mek} /+$, and PlpCre ${ }^{\mathrm{ERT}} ; \mathrm{Mek} / \mathrm{Mek}$ mice that were Tm injected at 2 months of age were double labeled with CC1 and EGFP at 1, 3, 6, and $8 \mathrm{MPI}$ (Fig. 7). We found that, at $1 \mathrm{MPI}$, the numbers of EGFP+ (recombined) oligodendrocytes were not significantly different in the $\mathrm{PlpCre}{ }^{\mathrm{ERT}} ; \mathrm{Mek} /+$ and the $\mathrm{PlpCre-}$ ${ }^{\mathrm{ERT}}$;Mek/Mek mice (Fig. 7B). However, by 3, 6, and $8 \mathrm{MPI}$, progressively fewer EGFP+ oligodendrocytes were found in the $\mathrm{PlpCre}^{\mathrm{ERT}}$;Mek/Mek mice compared with the PlpCre ${ }^{\mathrm{ERT}} ; \mathrm{Mek} /+$ mice. This could potentially be attributed to a partial loss of EGFP+ "recombined" oligodendrocytes with time or due to a downregulation of EGFP expression within oligodendrocytes. Although we cannot completely rule out the latter, because no reduction in EGFP + cells was noted in the $\mathrm{PlpCre}{ }^{\mathrm{ERT}} ; \mathrm{Mek} /+$ even up to $8 \mathrm{MPI}$, this suggests that EGFP expression is unlikely to be downregulated with time to undetectable levels in the line of mice used in our study. Further, to determine whether there were any obvious signs of cell death in the spinal cord white matter, we immunolabeleled sections for cleaved caspase-3 as a marker of apoptotic cells. We found that, whereas the presence of cleaved caspase-3+ cells was almost nonexistent in the control and PlpCre ${ }^{\mathrm{ERT}} ; \mathrm{Mek} /+$ mice, a statistically significant increase in the incidence of cleaved caspase-3+ cells was observed in the PlpCre ${ }^{\mathrm{ERT}}$;Mek/Mek mice (Fig. 7D).

Concurrent with the reduction in the EGFP+ cells there was an increase in the numbers of CC1+ cells at 6 and 8 MPI in the $\mathrm{PlpCre}{ }^{\mathrm{ERT}} ; \mathrm{Mek} / \mathrm{Mek}$ compared with control and PlpCre ${ }^{\mathrm{ERT}}$; Mek/+ mice (Fig. 7C). Double-labeled images of CC1 and EGFP showed that many of the CC1 + cells were EGFP - at these time points (Fig. $7 A$, bottom). It is plausible that in response to the partial loss of EGFP+ "recombined" oligodendrocyte, there was a partial repopulation and replacement by newly generated "non- 


\section{A}
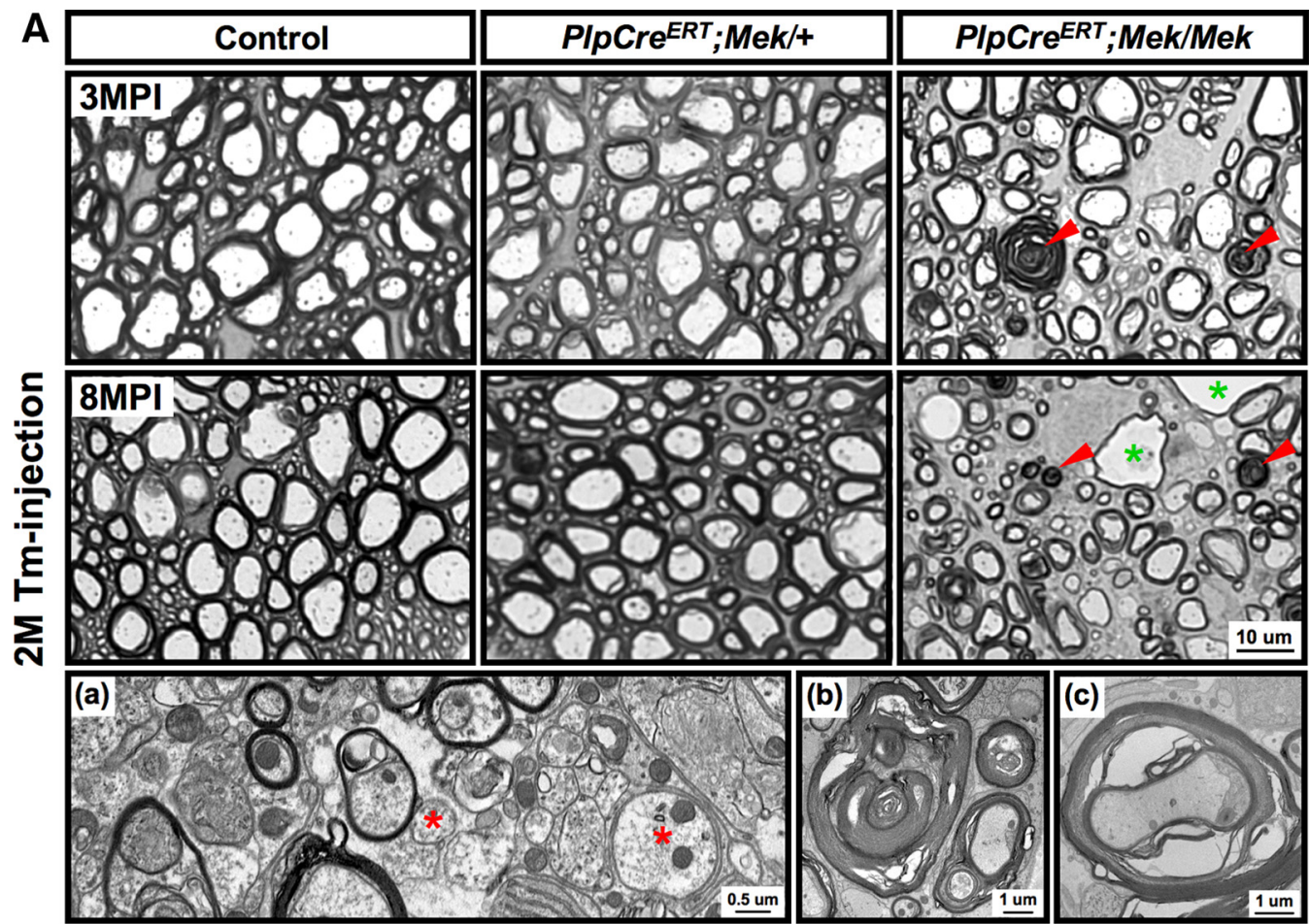

B

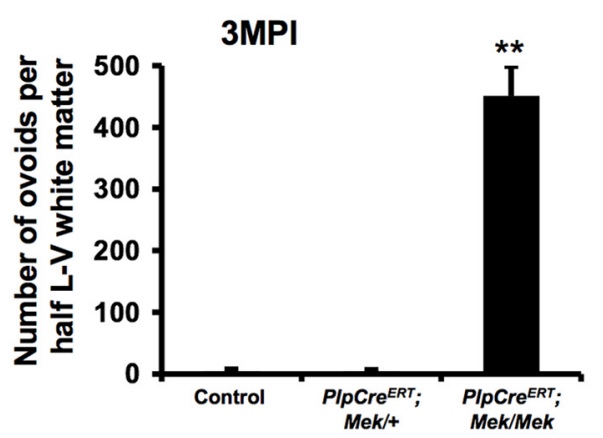

C
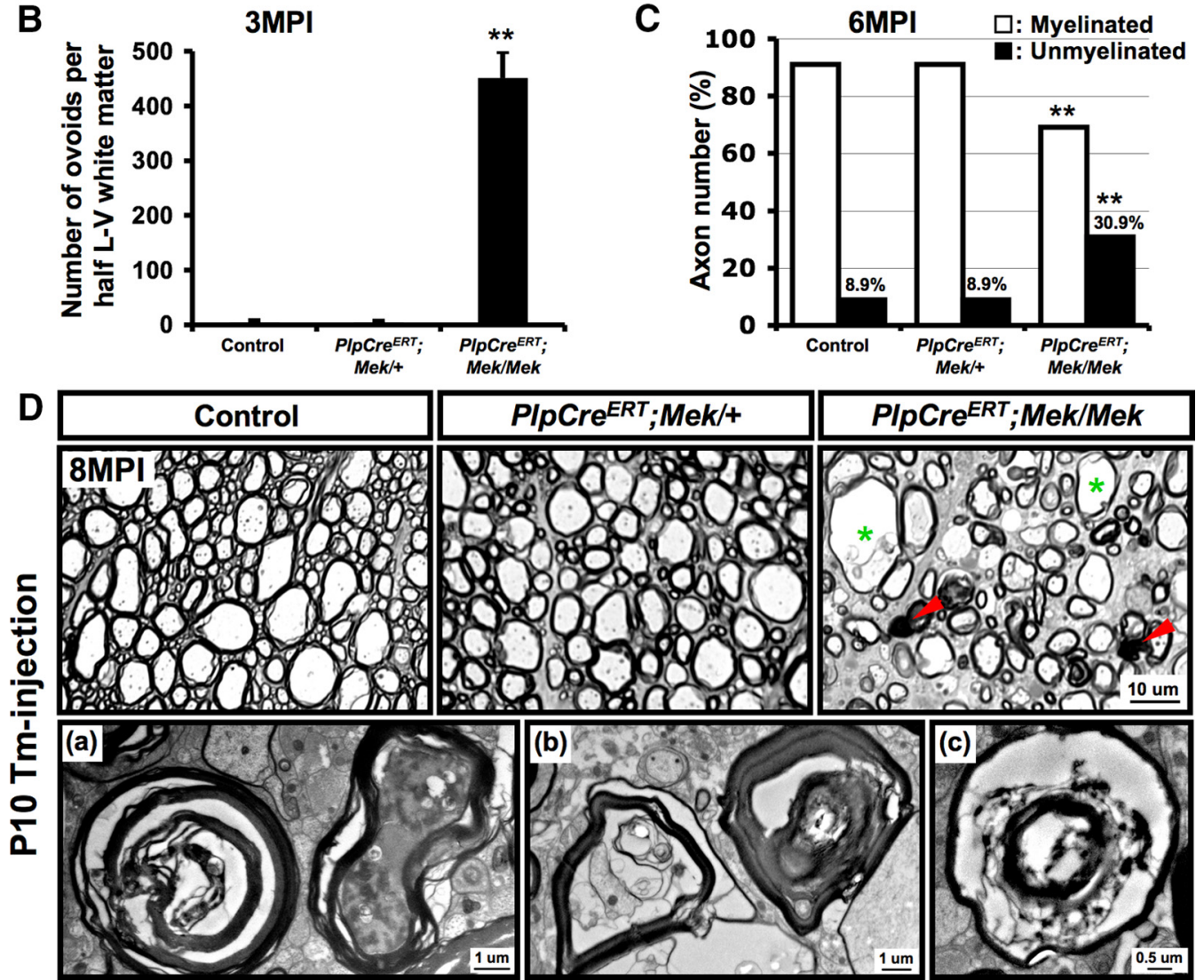

Figure 6. Increasing the strength of ERK1/2 activation in oligodendrocytes results in myelin and axonal pathology at higher doses (Mek/Mek), but not at lower doses (Mek/+) regardless of the timing of its activation. $A$, Transverse semithin sections of ventral spinal cord from control, PlpCre ${ }^{\text {ERT }}$;Mek/ + , and PlpCre ${ }^{\text {ERT } ; M e k / M e k ~ m i c e ~ i n j e c t e d ~ w i t h ~ T m ~ a t ~} 2$ months of age and analyzed at 3 and $8 \mathrm{MPI}$ show abnormal myelin profiles with darkly stained ovals (red arrowheads) and degenerating axons, which often appeared as empty spaces surrounded by thin wraps of myelin (green asterisk) in the PlpCre ${ }^{\mathrm{ERT}} ;$ Mek/Mek, but not in the PIpCre ${ }^{\mathrm{ERT}} ;$ Mek/+ or control mice. High-magnification EM images of ventral spinal cords from PlpCre ${ }^{\mathrm{ERT}} ;$ Mek/Mek mice at 8 MPI show unmyelinated (red asterisk) and thinly myelinated axons $(\boldsymbol{A a})$, redundant or collapsed myelin profiles representing myelin remaining after axonal loss $(\boldsymbol{A} \boldsymbol{b})$, and a degenerating axon with deteriorating myelin sheath (Ac) . B, Quantification of darkly stained ovals in half sections of lateral-ventral ( $(\mathrm{V}-\mathrm{V})$ white matter of spinal cord from mice injected with Tm at 2 months and analyzed at $3 \mathrm{MPI}$ show a statistically

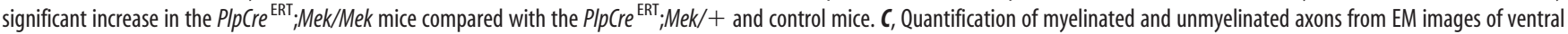
spinal cords shows that the percentage of unmyelinated axons is significantly higher in the PlpCre $e^{\text {ERT }}$;Mek/Mek mice ( $\left.\sim 31 \%\right)$ compared with control (Figure legend continues.) 

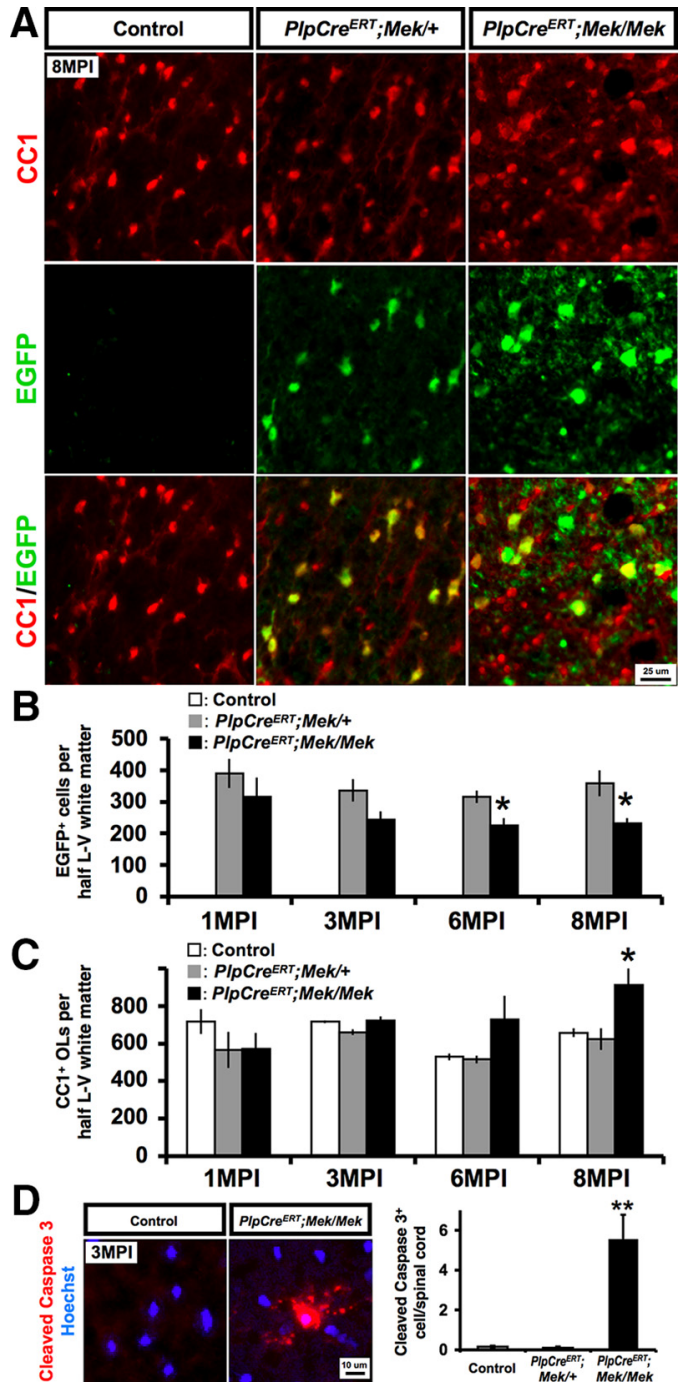

Figure 7. Viability of oligodendrocytes is partially affected at later ages in the PIpCre ${ }^{\text {ERT; }}$ $\mathrm{Mek} / \mathrm{Mek}$, but not in the PlpCre ${ }^{\mathrm{ERT}} ; \mathrm{Mek} /+$, mice. Spinal cord transverse sections from control, PlpCre ${ }^{\mathrm{ERT}} ; \mathrm{Mek} /+$, and PIpCre ${ }^{\mathrm{ERT}} ;$ Mek/Mek mice injected with Tm at 2 months were analyzed at 1,3,6, and $8 \mathrm{MPI}$. A, Double immunolabeling shows CC1 (red), EGFP (green), and merged image (yellow; $8 \mathrm{MPI}$ time point is shown). $\boldsymbol{B}$, Quantification of the total numbers of EGFP + oligodendrocytes in half-sections of lateral-ventral $(L-V)$ white matter shows that their numbers are progressively reduced in the $P I p C r e^{\mathrm{ERT}} ; M e k / M e k$ compared with $\mathrm{Plp}\left(\mathrm{re}^{\mathrm{ERT}} ; \mathrm{Mek} /+\right.$, reaching significance by 6 and $8 \mathrm{MPI}$. C, The numbers of $\mathrm{CC} 1+$ oligodendrocytes (OLs) in the PIpCre ${ }^{\mathrm{ERT}}$; $\mathrm{Mek} /+$ are comparable to the control and remain largely unchanged at all the time points, whereas in the PIpCre ${ }^{\mathrm{ERT}} ;$ Mek/Mek mice, they show an increase at $6 \mathrm{MPI}$ and reach significance at $8 \mathrm{MPI}$. D, Spinal cord sections immunolabeled for cleaved caspase-3 show significantly increased numbers of labeled cells in the PlpCre ${ }^{\text {ERT;}}$;Mek/Mek mice compared with PlpCre ${ }^{\text {ERT; }}$; $\mathrm{Mek} /+$ or control mice, indicative of increased cell death due to apoptosis. Three to four sections, each from three to five mice of each genotype, were analyzed. Error bars indicate SEM. ${ }^{*} p<0.05,{ }^{* *} p<0.01 . n=3-5$.

(Figure legend continued.) and PlpCre ${ }^{\mathrm{ERT}}$;Mek/+ mice $(\sim 9 \%)$ and the number of myelinated axons is significantly lower; 911 (control), 1284 (Mek/+), and 1442 (Mek/Mek) axons from two animals of each group were examined. $\boldsymbol{D}$, Transverse semithin sections of ventral spinal cord from control, PlpCre ${ }^{\mathrm{ERT}} ; \mathrm{Mek} /+$, and PlpCre ${ }^{\mathrm{ERT}}{ }_{;}$Mek/Mek mice injected with Tm at P10 and analyzed at $8 \mathrm{MPI}$ also show abnormal myelin profiles with darkly stained ovals (red arrowheads) and degenerating axons in the PlpCre ${ }^{\text {ERT }}$;Mek/Mek, but not in the PlpCre ${ }^{\mathrm{ERT}}$; Mek/+ or control mice. High-magnification EM images from PlpCre ${ }^{\text {ERT }}$;Mek/Mek (Da-Dc) show myelinated axonal profiles with axons in varying stages of degeneration. Multiple images of semithin and ultrathin sections from two to three mice per group were analyzed. recombined" oligodendrocytes (which have not undergone Cremediated recombination and therefore constitutive activation of Mek1), thus explaining the presence of a population of $\mathrm{CC} 1+\mathrm{EGFP}-$ cells in the PlpCre ${ }^{\mathrm{ERT}} ; \mathrm{Mek} / \mathrm{Mek}$ mice. A similar phenomenon of repopulation by "nonrecombined" oligodendrocytes after death of "recombined" oligodendrocytes has also been observed previously by others in another PlpCre ${ }^{\text {ERT }}$ line of mice in which Tm was injected in adults (Koenning et al., 2012). In addition, we observed an increase in Olig2 + cell number (data not shown) and signs of remyelination (thinner myelin) of the preserved demyelinated axons in the $\mathrm{PlpCre}{ }^{\mathrm{ERT}} ; \mathrm{Mek} / \mathrm{Mek}$ mice at later ages (Fig. 6Aa), which is consistent with the notion that, after the partial loss of recombined oligodendrocytes, there is a partial replacement by newly generated oligodendrocytes derived from nonrecombined oligodendrocyte progenitors. In contrast to the $\mathrm{PlpCre}{ }^{\mathrm{ERT}} ; \mathrm{Mek} / \mathrm{Mek}$, in the $\mathrm{PlpCre}{ }^{\mathrm{ERT}} ; \mathrm{Mek} /+$ mice, the total numbers of $\mathrm{CC} 1+$ cells or the EGFP + cells remained largely unchanged at all the ages examined, suggesting that EGFP expression is maintained in oligodendrocytes over long periods and that these EGFP+ recombined oligodendrocytes remain viable. Although we favor the interpretation that the viability of oligodendrocytes is partially affected at later ages in the $\mathrm{Plp}$ $\mathrm{Cre}^{\mathrm{ERT}}$;Mek/Mek mouse, the alternate interpretation that EGFP expression may be downregulated within oligodendrocytes is also a possibility.

Strong microglial activation and reactive astrocytosis occur in $\mathrm{PlpCre}{ }^{\mathrm{ERT}} ; \mathrm{Mek} / \mathrm{Mek}$, but not $\mathrm{PlpCre} e^{\mathrm{ERT}} ; \mathrm{Mek} /+$, mice

To assess potential secondary responses such as microglia activation and reactive astrocytosis to oligodendrocyte loss, demyelination, and/or axonal degeneration, we immunolabeled spinal cord sections from control, PlpCre ${ }^{\mathrm{ERT}} ; \mathrm{Mek} /+$ and $\mathrm{PlpCre}{ }^{\mathrm{ERT}} ; \mathrm{Mek} /$ Mek mice with antibodies against markers of astrocytes (GFAP) and microglia (IBA1; Fig. 8). PlpCre ${ }^{\mathrm{ERT}} ; \mathrm{Mek} / \mathrm{Mek}$ mice showed clear signs of progressive reactive astrogliosis with increased expression of GFAP both in the gray and white matter (Fig. $8 A$ ). Similarly, strong staining for IBA1 was observed in the PlpCre ${ }^{\mathrm{ERT}}$;Mek/Mek mice at 6 and $8 \mathrm{MPI}$ in the white and gray matter in activated microglia, characterized by thicker, shorter, less-branched processes compared with resting microglia in the controls, which have thinner, longer, more-branched processes (Fig. 8B). In contrast to the strong IBA1 and GFAP immunostaining in the $\mathrm{PlpCre}{ }^{\mathrm{ERT}} ; \mathrm{Mek} / \mathrm{Mek}$ mice, the PlpCre;Mek/+ mice showed only slight increases by 8 MPI. Increased astrocytosis and microglial activation were also observed in CnpCre;Mek/Mek, but not CnpCre;Mek/+, mice (data not shown).

We also examined microglial activation in the corpus callosum of control PlpCre ${ }^{\mathrm{ERT}} ; \mathrm{Mek} /+$ and PlpCre ${ }^{\mathrm{ERT}} ; \mathrm{Mek} / \mathrm{Mek}$ mice at 6 MPI. Similar to the spinal cord, an increase in IBA1 expression was observed in the corpus callosum of PlpCre ${ }^{\text {ERT }}$; Mek/Mek, but not PlpCre ${ }^{\mathrm{ERT}} ; \mathrm{Mek} /+$, mice compared with controls (Fig. 8C).

We conclude that oligodendrocyte/myelin/axonal pathology caused by superactivation of ERK1/2 in mature oligodendrocytes of the adult CNS leads to secondary pathological effects and an overall disruption of CNS homeostasis in the long term.

\section{Myelin/axonal pathology occur in the PNS by elevation of} ERK1/2 activity in Schwann cells

Because Cnp-Cre is also expressed by Schwann cells, in addition to oligodendrocytes (Gravel et al., 1998; Yuan et al., 2002; Doerflinger et al., 2003; Leone et al., 2003), the Schwann cells of the CnpCre;Mek/+ and CnpCre;Mek/Mek mice should also show 
graded elevation of ERK1/2 activity. This was validated by immunoblotting and quantification of phospho-ERK1/2 levels, which showed a statistically significant increase in ERK1/2 activity in the sciatic nerves of CnpCre;Mek/Mek compared with the CnpCre;Mek/+ or control mice (Fig. 9A).

We and others showed previously that moderate elevation of ERK1/2 in Schwann cells of Mek/ + mice resulted in increased myelin thickness during developmental myelination (Ishii et al., 2013; Sheean et al., 2014). Here, we investigated the long-term effects of increasing the strength and/or duration of sustained ERK1/2 activation on myelin and axonal integrity during adulthood. Sciatic nerve cross-sections from control, CnpCre; $\mathrm{Mek} /+$, and CnpCre;Mek/Mek mice were examined at 3 and 8 months of age. At 3 months, the toluidine-blue-stained semithin sections and EM images from CnpCre;Mek/Mek mice showed examples of abnormal myelin overgrowth forming numerous myelin figures with infoldings and outfoldings compressing axons and eventually leading to their degeneration (Fig. 9B,C). A milder pathology was observed in the CnpCre;Mek/+ mice at this age (Fig. 9B, top), which became more pronounced by 8 months of age (Fig. 9B, second panel). These observations were confirmed by the quantification of myelin/axon abnormalities in seminthin sections of sciatic nerves showing a statistically significant increase in the CnpCre;Mek/+, and CnpCre;Mek/Mek mice compared with control mice, as well as a statistically significant increase in the CnpCre;Mek/Mek mice compared with CnpCre;Mek/+ mice (percentage of total axons showing pathology, 3 months: control, $2.3 \pm 0.2 ;$ CnpCre;Mek/+, $26.5 \pm$ 1.6; CnpCre;Mek/Mek, $48.3 \pm 2.7$, oneway ANOVA $p<0.01 .8$ months: control, $3.2 \pm 0.6$; CnpCre; Mek/+, $38.3 \pm 2.5 ; p<$ $0.01,10$ fields at $100 \times$ per genotype were analyzed from at least 2 mice per group).

Abnormal myelin growth with focal myelin thickening originating at the paranodes, referred to as "tomacula," is a feature observed in the PNS of other mutant mice and human inherited peripheral neuropathies (Sander et al., 2000; Scherer and Wrabetz, 2008; Goebbels et al., 2012). To determine whether the abnormal myelin growth seen in cross-sections of the sciatic nerves (above) had tomacula-like features, we examined teased fiber preparations of sciatic nerves from control and CnpCre;Mek/+ mice by Sudan black staining (Fig. 9B, second panel). A dramatically abnormal myelin staining pattern was observed at the paranodal region, indicating focal thickening of myelin and formation of tomacula in these mice. matter.

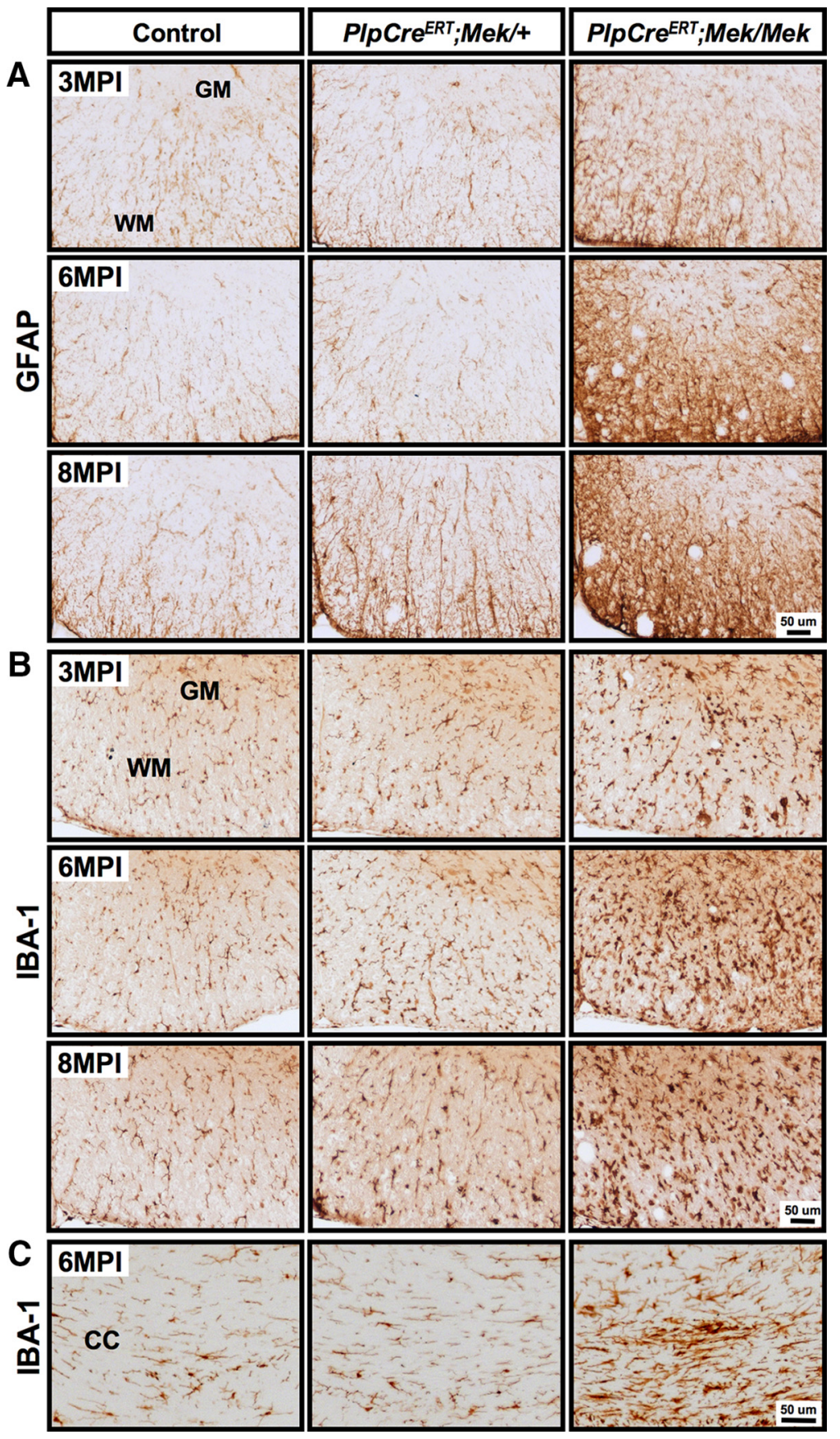

Figure 8. Strong microglial activation and reactive astrocytosis occur in PlpCre ${ }^{\mathrm{ERT}} ; \mathrm{Mek} / \mathrm{Mek}$, but not in the $\mathrm{PlpCre}{ }^{\mathrm{ERT}} ; \mathrm{Mek} /+$, mice. Transverse sections of cervical spinal cord from control, PlpCre ${ }^{\mathrm{ERT}} ; \mathrm{Mek} /+$, and $P / p\left(\mathrm{Cre}^{\mathrm{ERT}} ;\right.$ Mek/Mek mice immunolabeled for $\operatorname{GFAP}(\boldsymbol{A})$ or IBA-1 $(\boldsymbol{B})$ at 3,6 , and $8 \mathrm{MPI}$ show marked presence of reactive astrocytes and activated microglia, respectively, at 6 and $8 \mathrm{MPI}$ in the gray and white matter of $P I p C r e{ }^{\mathrm{ERT}} ; \mathrm{Mek} / \mathrm{Mek}$, but only a mild increase in the $P I p C r e^{\mathrm{ERT}} ; \mathrm{Mek} /+$, by $8 \mathrm{MPI}$ compared with control mice. C, Coronal sections from corpus callosum at $6 \mathrm{MPI}$ mice also show increased IBA1 staining in the PIpCre ${ }^{\mathrm{ERT}} ; \mathrm{Mek} /$ Mek, but not in the PIpCre ${ }^{\text {ERT }}$;Mek/+ and control mice. $n=3$; representative sections are shown. WM, White matter; GM, gray

We also examined the sciatic nerves of $P l p C r e^{\mathrm{ERT}} ; \mathrm{Mek} /+$ and $P l p C r e^{\text {ERT }} ; M e k / M e k$ mice injected with Tm at P10 (Fig. 9D). Similar to the findings described above, the toluidine-blue-stained semithin sections at 8 MPI showed myelin and axonal pathology in the $\mathrm{PlpCre}{ }^{\mathrm{ERT}} ; \mathrm{Mek} / \mathrm{Mek}$ mice and to a lesser extent in the $P l p C r e^{\text {ERT }} ; M e k /+$ mice. EM images showing examples of these abnormalities in the PlpCre ${ }^{\mathrm{ERT}}$;Mek/Mek mice include a myelinated axon that has completely degenerated, leaving only an unraveling myelin sheath, and axons with myelin sheaths with 
A

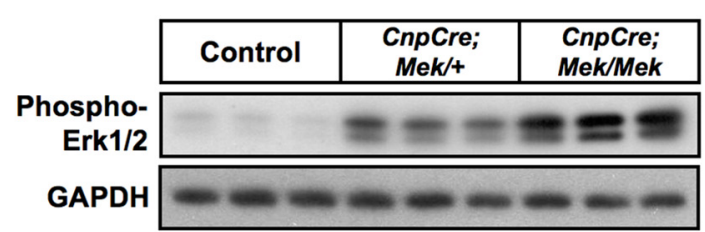

B
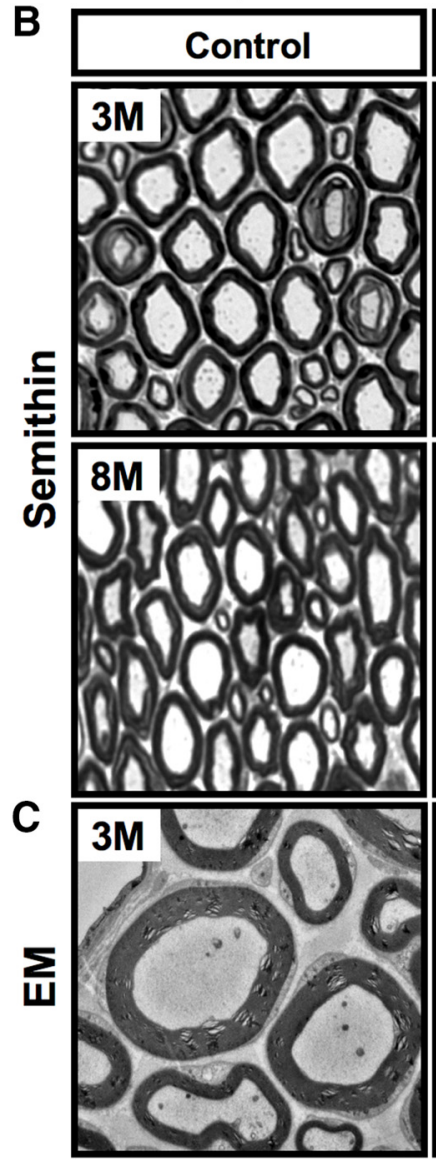

Control

$-m-m-\infty$

D
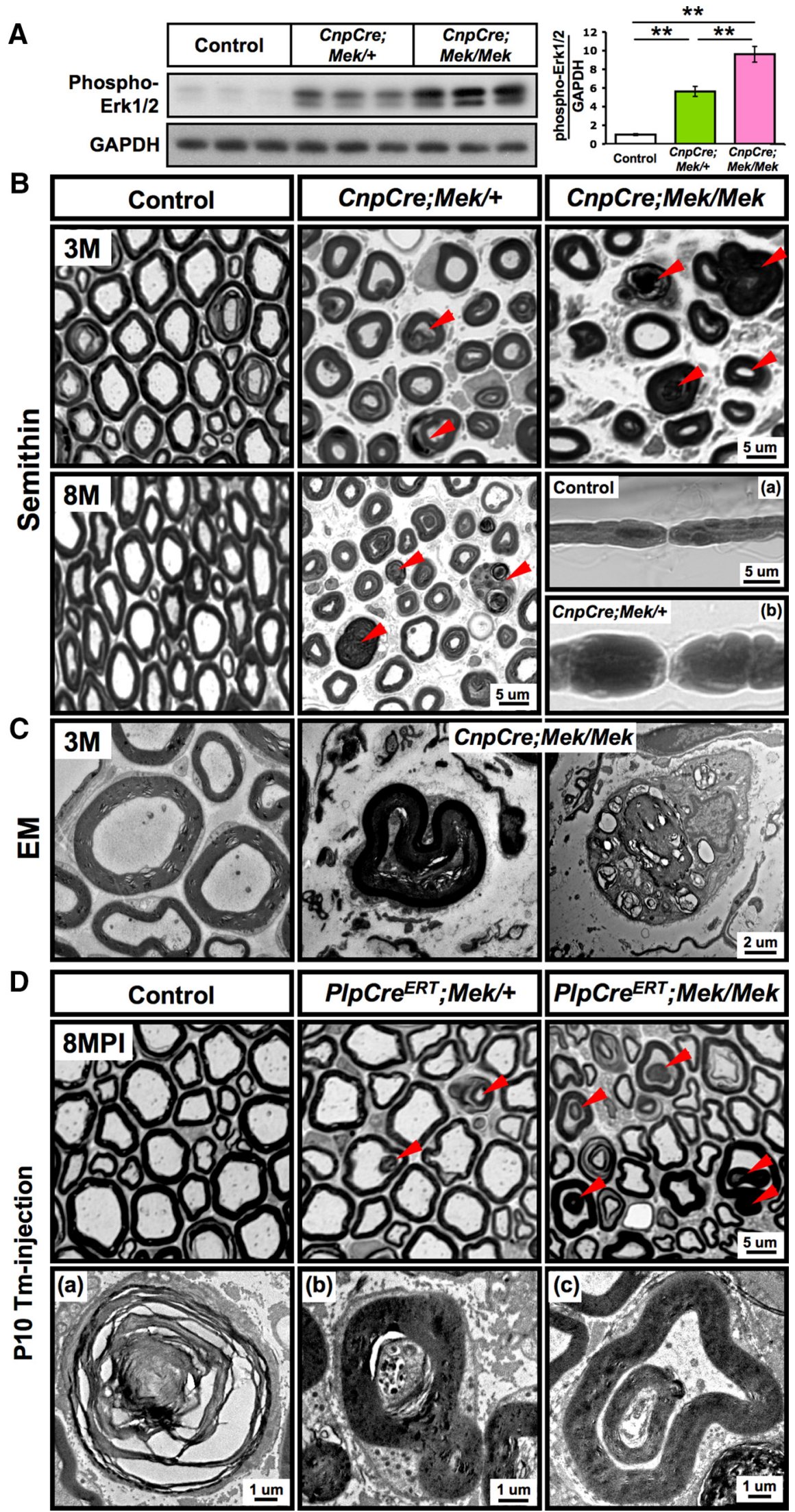

Figure 9. Myelin/axonal pathology occur in the PNS by elevation of ERK1/2 activity in Schwann cells. $A$, Immunoblot analysis of phospho-ERK1/2 in lysates of sciatic nerves from control, CnpCre;Mek/+, and CnpCre;Mek/Mek mice at P 21 shows a statistically significant graded elevation of ERK1/2 activity with increased dosage of constitutively active Mek 1 gene. Error bars represent SEM. ${ }^{* *} p<0.01$, one-way ANOVA. $n=3$. B , Toludine-blue-stained semithin sections of sciatic nerves at 3 months (M) show numerous abnormal myelin figures (examples shown by arrowheads) in the (npCre;Mek/Mek and to a lesser extent in the CnpCre;Mek/+ apparently abnormal membranous infolding and outfoldings appearing as concentric rings of myelin. These observations were confirmed by the quantification of the abnormalities in seminthin sections of sciatic nerves showing a statistically significant increase in the PlpCre ${ }^{\mathrm{ERT}} ; \mathrm{Mek} /+$ and $\mathrm{PlpCre}{ }^{\mathrm{ERT}} ; \mathrm{Mek} /$ Mek compared with control mice, as well a statistically significant increase in the PlpCre ${ }^{\mathrm{ERT}}$;Mek/Mek compared with $\mathrm{PlpCre}{ }^{\mathrm{ERT}} ; \mathrm{Mek} /+$ mice (percentage of total axons showing pathology, $8 \mathrm{MPI}$ : control, $3.1 \pm 0.8 ;$ PlpCre ${ }^{\mathrm{ERT}} ; \mathrm{Mek} /+, 10.6 \pm$ 1.2; PlpCre ${ }^{\mathrm{ERT}} ; \mathrm{Mek} / \mathrm{Mek}, 22.3 \pm 2.5 ; p<$ $0.01,10$ fields at $100 \times$ per genotype were analyzed from at least 2 mice per group).

The enlargement of the extracellular space (Fig. 9B) and size of the sciatic nerve (Fig. 10A) observed for the CnpCre;Mek/+ and CnpCre;Mek/Mek mice was not obvious for the $\mathrm{PlpCr} e^{\mathrm{ERT}} ; \mathrm{Mek} /+$ and $\mathrm{PlpCre} e^{\mathrm{ERT}}$; $\mathrm{Mek} / \mathrm{Mek}$ mice. Although the reason for this difference is not clear, it is possible that this phenomenon may be related to an earlier activation of Mek1 in Schwann cells using Cnp-Cre compared with the Tm-induced activation at $\mathrm{P} 10$ using $\mathrm{Plp}$-Cre mice. A similar phenomenon was also observed when Mek1 was activated in another line of transgenic mice using Egr2-Cre, which is expressed very early in Schwann cells (Sheean et al., 2014).

We conclude that, as in the CNS, increasing the strength of ERK1/2 activation

mice. By 8 months of age, myelin figures appear more pronounced in the Cnp(re;Mek/+ mice as well (percentage of total axons showing pathology, 3 months: control, $2.3 \pm 0.2 ;(\mathrm{Cn}$ (re; Mek/+, $26.5 \pm 1.6$; CnpCre;Mek/Mek, $48.3 \pm 2.7 . p<0.018$ months: control, $3.2 \pm 0.6$; (npCre;Mek/+, $38.3 \pm 2.5 . p<0.01$, 10 fields at $100 \times$ per genotype were analyzed from at least two mice per group). $\boldsymbol{A} \boldsymbol{a}, \boldsymbol{A} \boldsymbol{b}$, Sudan black staining of teased fiber preparation of sciatic nerve shows thickening of myelin (tomacula) at the paranodes in the CnpCre;Mek/+ mice, but not in the control mice. C, EM images of sciatic nerves at high magnification from 8-month-old CnpCre;Mek/Mek mice showing examples of abnormal myelin infoldings and axonal degeneration. $\boldsymbol{D}$, Toludine-blue-stained semithin sections of sciatic nerves from control, PlpCre ${ }^{\mathrm{ERT}} ; \mathrm{Mek} /+$, and PlpCre ${ }^{\mathrm{ERT}}$; Mek/Mek mice injected with Tm at P10 and analyzed at 8 MPI show numerous abnormal myelin figures (arrowheads show examples) in the $P I p\left(r e{ }^{\text {ERT }}\right.$;Mek/Mek mice and, to a lesser extent, in the PlpCre ${ }^{\mathrm{ERT}} ; M e k /+$ (percentage of total axons showing abnormal myelin figures: control, $3.1 \pm 0.8$; PlpCre${ }_{\mathrm{ERT}}^{\mathrm{E}}$;Mek/+, 10.6 $\pm 1.2 ;$ PlpCre ${ }^{\mathrm{ERT}} ;$ Mek/Mek, $22.3 \pm 2.5 ; p<$ $0.01,10100 \times$ fields per genotype were analyzed from at least two mice per group). EM images show a myelinated axon that has completely degenerated leaving only an unraveling myelin sheath $(\boldsymbol{D a})$ and axons with myelin sheaths with apparently abnormal membranous infolding and outfoldings appearing as concentric rings of myelin $(\boldsymbol{D b}, \boldsymbol{D C})$. Representative images are shown from two mice per genotype. 
in myelinating Schwann cells leads to abnormal myelin formation and axonal degeneration in the PNS. In addition, because, with age, these defects tend to become more prominent in the Mek/+ mice as well, it is likely that the duration of sustained ERK1/2 activation may also play a role in determining the outcome of ERK1/2 activation in the PNS.

Increased collagen deposition and mast cell infiltration occur in the sciatic nerves by elevation of ERK1/2 activity in Schwann cells

In addition to the abnormalities described above, we consistently observed that the sciatic nerves were abnormally larger in the CnpCre;Mek/+ and even more so in the CnpCre;Mek/Mek mice compared with controls (Fig. 10A). Furthermore, as shown earlier, compared with controls, the CnpCre;Mek/Mek mice and, to a lesser extent, the CnpCre;Mek/+ mice showed enlargement of extracellular space with increased spacing between axons (Fig. 9B, top). We therefore hypothesized that increased deposition of extracellular matrix proteins such as collagen could in part lead to this enlargement as a result of ERK1/2 overstimulation in Schwann cells. We therefore examined the relative levels of collagen deposition by Masson's trichrome staining (blue) in longitudinal sections of sciatic nerves from control, CnpCre;Mek/+ and CnpCre;Mek/Mek mice (Fig. 10B). At 3 months of age, an increase in the deposition of collagen was observed in the CnpCre;Mek/Mek and, to a lesser extent, in CnpCre;Mek/+ mice compared with controls. By 8 months of age, strong staining of Masson's trichrome also appeared in the CnpCre; $\mathrm{Mek} /+$ mice. The presence of collagen fibers was confirmed by EM analysis of sciatic nerves of mutant mice (Fig. 10B).

A role of mast cells in the development of Schwann-cell-mediated nerve pathology has been proposed (Monk et al., 2007). We therefore examined potential mast cell infiltration by Giemsa staining (blue) of longitudinal sections of sciatic nerves from control, CnpCre;Mek/+, and CnpCre;Mek/Mek mice (Fig. 10C). At 3 months of age, a significant number of mast cells were observed in CnpCre;Mek/Mek and, to a lesser extent, in CnpCre;Mek/+ mice compared with controls (number of mast cells/field: control, $0.6 \pm 0.3$; CnpCre;Mek/+, $5.5 \pm 0.3$; CnpCre;Mek/Mek, $9.9 \pm 0.3 . p<0.01, \sim 9$ fields at $20 \times$ were counted from 3 animals per genotype). By 8 months of age, the increase in mast cells became more obvious in CnpCre;Mek/+ mice, as well (12.5 \pm 1.8 cells/field). EM analysis confirmed the presence of mast cells in the sciatic nerves of these mice (Fig. 10C).

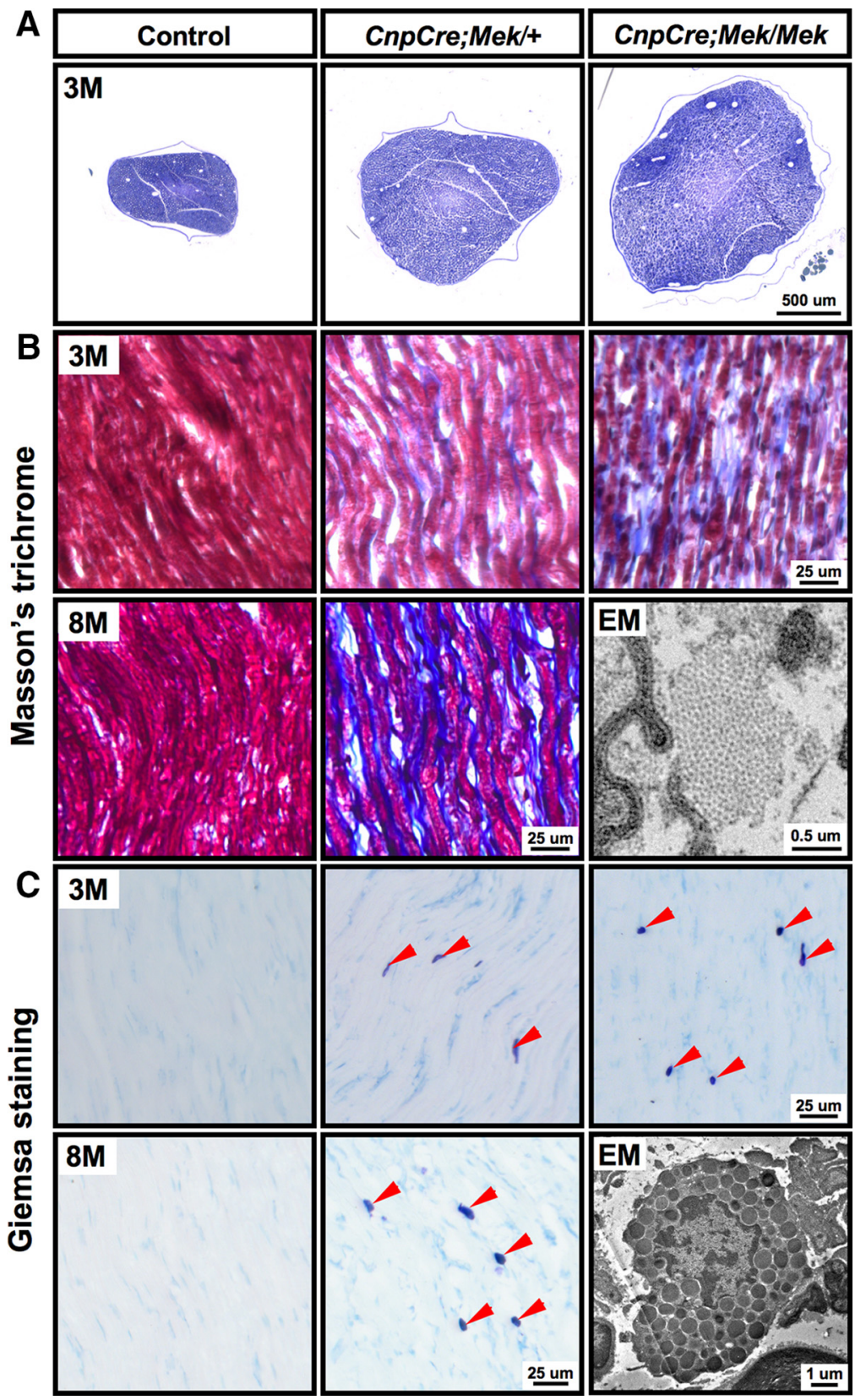

Figure 10. Increased collagen deposition and mast cell infiltration occur in the sciatic nerves by superelevation of ERK1/2 activity in Schwann cells. $\boldsymbol{A}$, Gross micrographs showing enlargement of sciatic nerves of (npCre;Mek/+ and (np(re;Mek) Mek mice compared with controls at 3 months of age (M). $\boldsymbol{B}$, Collagen deposition, shown by Masson's trichrome staining (blue) in longitudinal sections of sciatic nerves at 3 months, is enhanced in the CnpCre;Mek/Mek compared with the CnpCre;Mek/+ mice. By 8 months, staining intensity also increases in the CnpCre;Mek/+ mice. EM image of sciatic nerve shows collagen fibers in the $\mathrm{Cnp}$ Cre;Mek/Mek mice. C, Mast cell infiltration, shown by Giemsa staining (blue) in longitudinal sections of sciatic nerves, is increased at 3 months in the $\mathrm{CnpCre;Mek/Mek} \mathrm{compared} \mathrm{with} \mathrm{the} \mathrm{CnpCre;Mek/+} \mathrm{mice} \mathrm{(number}$ of mast cells/field: control, $0.6 \pm 0.3 ; \mathrm{CnpCre;Mek/+,5.5 \pm 0.3;CnpCre;Mek/Mek,9.9 \pm 0.3.p<0.01,} \sim 9$ fields at $20 \times$ were counted from 3 animals per genotype. By 8 months, mast cell numbers are further increased in the $\mathrm{CnpCre;Mek/+}$ mice, as well (12.5 \pm 1.8 cells/field). EM image shows mast cells in the sciatic nerves of these mice. Representative images are shown from three mice per genotype.

We conclude that a disrupted axon-Schwann cell interaction caused by hyperactivation of ERK1/2 in Schwann cells is accompanied by increased collagen deposition and inflammatory reactions such as mast cell infiltration.

\section{Discussion}

Here, we show that moderate upregulation of ERK1/2 activity $(\mathrm{Mek} /+)$ in quiescent oligodendrocytes during adulthood upregu- 
lates myelin gene expression and reinitiates new myelin growth by preexisting oligodendrocytes even after active myelination is largely terminated. Paradoxically, regardless of whether commenced during developmental myelination or during adulthood, hyperactivation of ERK1/2 (Mek/Mek) led to progressive neurological deficits, demyelination and dysmyelination, and axonal degeneration accompanied by inflammatory reactions in the adult CNS and PNS.

Our findings that ERK1/2 activation can induce adult oligodendrocytes to upregulate myelin gene expression and reinitiate new myelin growth during adulthood is consistent with the notion that mature quiescent oligodendrocytes retain a certain amount of plasticity and that, given the right signal, they can return to a more metabolically active state to assemble new myelin, even after active myelination is largely terminated. Recent studies suggest that myelination can serve as a form of plasticity to adapt brain function to environmental stimuli and that altering myelin growth to neuronally derived signals (activity or growth factor) is one potential mechanism (Fields, 2008; Liu et al., 2012; Makinodan et al., 2012; Mckenzie et al., 2014; Fields, 2015; Purger et al., 2015). For example, social isolation of adolescent or adult mice resulted in behavioral and cognitive dysfunction that correlated with reduced myelin gene expression and reduced myelin thickness in the prefrontal cortex, which were normalized upon social reintegration (Liu et al., 2012; Makinodan et al., 2012). It is possible that ERK1/2 signaling may be part of the overall molecular mechanism underlying myelin plasticity during adulthood. Interestingly, reinitiation of myelin growth was also observed when the P13K pathway was overstimulated in adult oligodendrocytes (Goebbels et al., 2010; Snaidero et al., 2014). It is possible that the ERK1/2-MAPK and P13K pathways converge within oligodendrocytes at one or more levels to corporate with each other or may act as independent parallel pathways to promote the reinitiation of myelination in adulthood.

It is known that, after demyelination, myelin fails to attain normal thickness during remyelination (Ludwin and Maitland, 1984; Franklin, 2002). Our previous and present genetic loss- and gain-of-function studies have strongly implicated a role of ERK1/2 in the regulation of myelin gene expression and myelin thickness during developmental myelination and during adulthood (Ishii et al., 2012; Ishii et al., 2013; Ishii et al., 2014). Further, moderate stimulation of ERK1/2 activity, at least in the CnpCre; $\mathrm{Mek} /+$ mice, was shown to increase myelin thickness and accelerate remyelination (Fyffe-Maricich et al., 2013). Together, these studies suggest that activation of ERK1/2 is a beneficial signal for normal growth and maintenance of myelin and for remyelination. However, there is also correlative evidence that predicts a detrimental role for ERK1/2 activation in oligodendrocytes. Specifically, exposure of differentiated oligodendrocytes in vitro to high doses of glial growth factor, an isoform of neuregulin 1 , or to FGF2 results in ERK1/2 activation, along with phenotypic reversion of oligodendrocytes, downregulation of myelin proteins, and aberrant reentry into the cell cycle (Fressinaud et al., 1995; Bansal and Pfeiffer, 1997; Canoll et al., 1999). Similarly, there is strong evidence that suggests a negative effect of increased activation of this pathway in Schwann cells (Harrisingh et al., 2004; Ogata et al., 2004; Napoli et al., 2012). We hypothesized that one reason for these paradoxical observations could be that when elevation of ERK1/2 activity commences during developmental myelination, it would result in increased but normal myelin growth, whereas when it is induced during adulthood, after active myelination is largely terminated, it would trigger myelin breakdown. Alternatively, the outcome of ERK1/2 activation could depend on the strength of its activation, such that moderate increase would lead to increased myelin growth, but when hyperactivated over an optimal threshold, it would become detrimental. Our present studies addressed both of these possibilities and found that hyperactivation of ERK1/2, either during developmental myelination or during adulthood resulted in myelin breakdown and axonal degeneration, whereas no such negative effects were seen in either of the heterzygote mice $(\mathrm{Mek} /+)$, in which ERK1/2 activity was moderately elevated either early or late. We therefore suggest that the strength of the ERK1/2 signal generated within the mature oligodendrocytes is a key determinant of the outcome of its activation regardless of the timing of ERK1/2 stimulation. This may account for the variability among earlier studies reporting both beneficial and detrimental effects of ERK1/2 activation. More importantly, this study suggests that the strength of ERK1/2 upregulation will need to be considered carefully before applying it as a therapeutic tool to promote remyelination in humans.

What may be the mechanism of demyelination or dysmyelination that occurs after hyperactivation of ERK1/2 over a critical threshold in the PlpCre ${ }^{\mathrm{ERT}}$;Mek/Mek mice? One possibility is that overproduction of myelin may eventually result in an overall destabilization of already established myelin structure, leading to its eventual breakdown and degeneration of axons. Interestingly, overexpression of Ras, an upstream mediator of ERK1/2 signaling, also showed adverse effects on myelin in transgenic mice (Mayes et al., 2013). Further, we have observed a reduction in the numbers of recombined oligodendrocytes with age in the PlpCre ${ }^{\mathrm{ERT}} ; \mathrm{Mek} / \mathrm{Mek}$, but not the $\mathrm{PlpCr} e^{\mathrm{ERT}} ; \mathrm{Mek} /+$ and control mice. Therefore, progressive death of mature oligodendrocytes could also contribute to progressive myelin breakdown and demyelination. Nevertheless, regardless of the mechanism, these studies clearly show a detrimental outcome of ERK1/2 hyperactivation on oligodendrocytes, myelin, and axons, underscoring the need for a potential termination signal to downregulate ERK1/2 activity in oligodendrocytes once active myelination is normally completed. Although mechanisms of termination of ERK1/2 activity have been proposed (Dickinson and Keyse, 2006), the termination signal in oligodendrocytes remains to be investigated, as Dlg1-PTEN has been suggested for the P13K pathway, at least in Schwann cells (Cotter et al., 2010; Goebbels et al., 2012).

The observed ERK1/2 dose-dependent increase in oligodendrocyte size in the Mek/+ and Mek/Mek mice suggests a direct or indirect involvement of ERK1/2 in maintaining oligodendrocyte cell size. The regulation of cell size is a dynamic process, balancing protein synthesis and degradation pathways, together providing homeostasis, dysregulation of which contributes to human pathologies (Lloyd, 2013). A well characterized pathway shown to regulate cell growth and size is the PI3K/Akt/mTOR pathway (Laplante and Sabatini, 2012; Tumaneng et al., 2012). In fact, hypertrophy of oligodendrocytes was shown to occur when this pathway was overstimulated (Goebbels et al., 2010). mTORC1 is a central mediator of multiple growth signals, and its increased activity promotes multiple protein and lipid biogenic processes (Locasale and Cantley, 2011). Therefore, our current data showing that mTOR activity is increased in oligodendrocytes in the PlpCre ${ }^{\mathrm{ERT}} ; \mathrm{Mek} /+$ and PlpCre ${ }^{\mathrm{ERT}} ; \mathrm{Mek} / \mathrm{Mek}$ mice suggest that this could be one potential mechanism by which ERK1/2 activity could modulate oligodendrocyte cell size.

Previous studies have shown that moderate activation of ERK1/2 in Schwann cells in the Mek/ + mice led to increased myelin growth in the PNS (Ishii et al., 2013; Sheean et al., 2014). Our present studies show that, when ERK1/2 activity in Schwann 
cells is hyperelevated, as in the Mek/Mek mice, it leads to strong adverse effects on myelin and axonal integrity in the PNS. The dramatic myelin pathology, including hypermyelination, myelin outfolding, and tomacula-like structures, that we observed in the sciatic nerves of Mek/Mek mice is very similar to that seen in the conditional Pten knock-out mice (Goebbels et al., 2012). It was proposed that these neuropathological features occur due to overstimulation of Akt/mTOR in Schwann cells and resemble those seen in a diverse group of inherited peripheral neuropathies such as human Charcot-Marie-Tooth disease and Hereditary Neuropathy with liability to Pressure Palsies (Sander et al., 2000; Goebbels et al., 2012). Given the similarity in the phenotypes of Mek/Mek and Pten knock-out mice, it is plausible that ERK1/2 may also directly or indirectly contribute to the manifestation of these neuropathological features of human diseases. Other adverse outcomes have also been attributed to overactivation of ERK1/2 in the PNS. Specifically, superactivation of Raf in adult Schwann cells led to Schwann cell dedifferentiation, demyelination, and infiltration of immune cells, similar to that seen after nerve injury but without damage to axons (Napoli et al., 2012). Our Mek/Mek mice also showed an increase in mast cell infiltration, in addition to myelin pathology (above). The fact that all of these phenotypes were more pronounced and appeared at an earlier age in the Mek/Mek compared with the Mek/+ mice reinforces the idea that the strength of ERK1/2 activation plays an important role in determining the biological outcome in both the CNS and PNS.

In summary, we show here that ERK1/2 activation in mature quiescent oligodendrocytes during adulthood is capable of reinitiating new myelin growth by preexisting oligodendrocytes, even after active myelination is terminated. These findings have important implications for understanding the molecular mechanisms underlying plasticity of myelin in adult life. Paradoxically, increasing the "strength" of ERK1/2 activation adversely affects myelin and axonal integrity in both the CNS and PNS. Therefore, a fine tuning of ERK1/2 signaling strength is critically important for optimal myelin growth and maintenance. Disturbance of this balance can result in detrimental rather than beneficial outcomes. Therefore, achieving a critical threshold of ERK1/2 activation will have to be considered carefully before its potential therapeutic application in demyelinating diseases or peripheral neuropathies.

\section{References}

Bansal R, Pfeiffer SE (1997) FGF-2 converts mature oligodendrocytes to a novel phenotype. J Neurosci Res 50:215-228. Medline

Canoll PD, Kraemer R, Teng KK, Marchionni MA, Salzer JL (1999) GGF/ neuregulin induces a phenotypic reversion of oligodendrocytes. Mol Cell Neurosci 13:79-94. CrossRef Medline

Cotter L, Ozçelik M, Jacob C, Pereira JA, Locher V, Baumann R, Relvas JB, Suter U, Tricaud N (2010) Dlg1-PTEN interaction regulates myelin thickness to prevent damaging peripheral nerve overmyelination. Science 328:1415-1418. CrossRef Medline

Crawley JN (2007) What's wrong with my mouse? In: Behavioral phenotype of transgenic and knockout mice (Crawley JN, ed), pp 62-109. New York: Wiley.

Dickinson RJ, Keyse SM (2006) Diverse physiological functions for dualspecificity MAP kinase phosphatases. J Cell Sci 119:4607-4615. CrossRef Medline

Dikic I, Schlessinger J, Lax I (1994) PC12 cells overexpressing the insulin receptor undergo insulin-dependent neuronal differentiation. Curr Biol 4:702-708. CrossRef Medline

Doerflinger NH, Macklin WB, Popko B (2003) Inducible site-specific recombination in myelinating cells. Genesis 35:63-72. CrossRef Medline

Ebisuya M, Kondoh K, Nishida E (2005) The duration, magnitude and compartmentalization of ERK MAP kinase activity: mechanisms for providing signaling specificity. J Cell Sci 118:2997-3002. CrossRef Medline

Fields RD (2008) White matter in learning, cognition and psychiatric disorders. Trends Neurosci 31:361-370. CrossRef Medline

Fields RD (2015) A new mechanism of nervous system plasticity: activitydependent myelination. Nat Rev Neurosci 16:756-767. CrossRef Medline

Fortin D, Rom E, Sun H, Yayon A, Bansal R (2005) Distinct fibroblast growth factor (FGF)/FGF receptor signaling pairs initiate diverse cellular responses in the oligodendrocyte lineage. J Neurosci 25:7470-7479. CrossRef Medline

Franklin RJ (2002) Why does remyelination fail in multiple sclerosis? Nat Rev Neurosci 3:705-714. CrossRef Medline

Fressinaud C, Vallat JM, Labourdette G (1995) Basic fibroblast growth factor down-regulates myelin basic protein gene expression and alters myelin compaction of mature oligodendrocytes in vitro. J Neurosci Res 40: 285-293. CrossRef Medline

Furusho M, Kaga Y, Ishii A, Hébert JM, Bansal R (2011) Fibroblast growth factor signaling is required for the generation of oligodendrocyte progenitors from the embryonic forebrain. J Neurosci 31:5055-5066. CrossRef Medline

Furusho M, Dupree JL, Nave KA, Bansal R (2012) Fibroblast growth factor receptor signaling in oligodendrocytes regulates myelin sheath thickness. J Neurosci 32:6631-6641. CrossRef Medline

Fyffe-Maricich SL, Schott A, Karl M, Krasno J, Miller RH (2013) Signaling through ERK1/2 controls myelin thickness during myelin repair in the adult central nervous system. J Neurosci 33:18402-18408. CrossRef Medline

Goebbels S, Oltrogge JH, Kemper R, Heilmann I, Bormuth I, Wolfer S, Wichert SP, Möbius W, Liu X, Lappe-Siefke C, Rossner MJ, Groszer M, Suter U, Frahm J, Boretius S, Nave KA (2010) Elevated phosphatidylinositol 3,4,5-trisphosphate in glia triggers cell-autonomous membrane wrapping and myelination. J Neurosci 30:8953-8964. CrossRef Medline

Goebbels S, Oltrogge JH, Wolfer S, Wieser GL, Nientiedt T, Pieper A, Ruhwedel T, Groszer M, Sereda MW, Nave KA (2012) Genetic Disruption of PTEN in a novel mouse model of tomaculous neuropathy. EMBO Mol Med 4:486-499. CrossRef Medline

Gravel M, Di Polo A, Valera PB, Braun PE (1998) Four-kilobase sequence of the mouse CNP gene directs spatial and temporal expression of lacZ in transgenic mice. J Neurosci Res 53:393-404. Medline

Harrisingh MC, Perez-Nadales E, Parkinson DB, Malcolm DS, Mudge AW, Lloyd AC (2004) The Ras/Raf/ERK signaling pathway drives Schwann cell dedifferentiation. EMBO J 23:3061-3071. CrossRef Medline

Ishii A, Fyffe-Maricich SL, Furusho M, Miller RH, Bansal R (2012) ERK1/ ERK2 MAPK signaling is required to increase myelin thickness independent of oligodendrocyte differentiation and initiation of myelination. J Neurosci 32:8855-8864. CrossRef Medline

Ishii A, Furusho M, Bansal R (2013) Sustained activation of ERK1/2 MAPK in oligodendrocytes and Schwann cells enhances myelin growth and stimulates oligodendrocyte progenitor expansion. J Neurosci 33:175-186. CrossRef Medline

Ishii A, Furusho M, Dupree JL, Bansal R (2014) Role of ERK1/2 MAPK signaling in the maintenance of myelin and axonal integrity in the adult CNS. J Neurosci 34:16031-16045. CrossRef Medline

Kaga Y, Shoemaker WJ, Furusho M, Bryant M, Rosenbluth J, Pfeiffer SE, Oh L, Rasband M, Lappe-Siefke C, Yu K, Ornitz DM, Nave KA, Bansal R (2006) Mice with conditional inactivation of fibroblast growth factor receptor-2 signaling in oligodendrocytes have normal myelin but display dramatic hyperactivity when combined with Cnpl inactivation. J Neurosci 26:12339-12350. CrossRef Medline

Katz M, Amit I, Yarden Y (2007) Regulation of MAPKs by growth factors and receptor tyrosine kinases. Biochim Biophys Acta 1773:1161-1176. CrossRef Medline

Koenning M, Jackson S, Hay CM, Faux C, Kilpatrick TJ, Willingham M, Emery B (2012) Myelin gene regulatory factor is required for maintenance of myelin and mature oligodendrocyte identity in the adult CNS. J Neurosci 32:12528-12542. CrossRef Medline

Laplante M, Sabatini DM (2012) mTOR signaling in growth control and disease. Cell 149:274-293. CrossRef Medline

Lappe-Siefke C, Goebbels S, Gravel M, Nicksch E, Lee J, Braun PE, Griffiths IR, Nave KA (2003) Disruption of Cnpl uncouples oligodendroglial functions in axonal support and myelination. Nat Genet 33:366-374. CrossRef Medline 
Leone DP, Genoud S, Atanasoski S, Grausenburger R, Berger P, Metzger D, Macklin WB, Chambon P, Suter U (2003) Tamoxifen-inducible gliaspecific Cre mice for somatic mutagenesis in oligodendrocytes and Schwann cells. Mol Cell Neurosci 22:430-440. CrossRef Medline

Liu J, Dietz K, DeLoyht JM, Pedre X, Kelkar D, Kaur J, Vialou V, Lobo MK, Dietz DM, Nestler EJ, Dupree J, Casaccia P (2012) Impaired adult myelination in the prefrontal cortex of socially isolated mice. Nat Neurosci 15:1621-1623. CrossRef Medline

Lloyd AC (2013) The regulation of cell size. Cell 154:1194-1205. CrossRef Medline

Locasale JW, Cantley LC (2011) Metabolic flux and the regulation of mammalian cell growth. Cell Metab 14:443-451. CrossRef Medline

Ludwin SK, Maitland M (1984) Long-term remyelination fails to reconstitute normal thickness of central myelin sheaths. J Neurol Sci 64:193-198. CrossRef Medline

Makinodan M, Rosen KM, Ito S, Corfas G (2012) A critical period for social experience-dependent oligodendrocyte maturation and myelination. Science 337:1357-1360. CrossRef Medline

Mayes DA, Rizvi TA, Titus-Mitchell H, Oberst R, Ciraolo GM, Vorhees CV, Robinson AP, Miller SD, Cancelas JA, Stemmer-Rachamimov AO, Ratner N (2013) Nf1 loss and Ras hyperactivation in oligodendrocytes induce NOS-driven defects in myelin and vasculature. Cell Rep 4:1197-1212. CrossRef Medline

McKenzie IA, Ohayon D, Li H, de Faria JP, Emery B, Tohyama K, Richardson WD (2014) Motor skill learning requires active central myelination. Science 346:318-322. CrossRef Medline

Monk KR, Wu J, Williams JP, Finney BA, Fitzgerald ME, Filippi MD, Ratner N (2007) Mast cells can contribute to axon-glial dissociation and fibrosis in peripheral nerve. Neuron Glia Biol 3:233-244. CrossRef Medline

Napoli I, Noon LA, Ribeiro S, Kerai AP, Parrinello S, Rosenberg LH, Collins MJ, Harrisingh MC, White IJ, Woodhoo A, Lloyd AC (2012) A central role for the ERK-signaling pathway in controlling Schwann cell plasticity and peripheral nerve regeneration in vivo. Neuron 73:729-742. CrossRef Medline

Nave KA, Trapp BD (2008) Axon-glial signaling and the glial support of axon function. Annu Rev Neurosci 31:535-561. CrossRef Medline

Ogata T, Iijima S, Hoshikawa S, Miura T, Yamamoto S, Oda H, Nakamura K, Tanaka S (2004) Opposing extracellular signal regulated kinase and Akt pathways control Schwann cell myelination. J Neurosci 24:6724-6732. CrossRef Medline

Purger D, Gibson EM, Monje M (2015) Myelin plasticity in the central nervous system. Neuropharmacology. In press.

Sander S, Ouvrier RA, McLeod JG, Nicholson GA, Pollard JD (2000) Clinical syndromes associated with tomacula or myelin swellings in sural nerve biopsies. J Neurol Neurosurg Psychiatry 68:483-488. CrossRef Medline

Scherer SS, Wrabetz L (2008) Molecular mechanisms of inherited demyelinating neuropathies. Glia 56:1578-1589. CrossRef Medline

Sheean ME, McShane E, Cheret C, Walcher J, Müller T, Wulf-Goldenberg A, Hoelper S, Garratt AN, Krüger M, Rajewsky K, Meijer D, Birchmeier W, Lewin GR, Selbach M, Birchmeier C (2014) Activation of MAPK overrides the termination of myelin growth and replaces Nrg1/ErbB3 signals during Schwann cell development and myelination. Genes Dev 28: 290-303. CrossRef Medline

Simons M, Nave KA (2015) Oligodendrocytes: myelination and axonal support. Cold Spring Harb Perspect Biol 8:a020479. CrossRef Medline

Snaidero N, Möbius W, Czopka T, Hekking LH, Mathisen C, Verkleij D, Goebbels S, Edgar J, Merkler D, Lyons DA, Nave KA, Simons M (2014) Myelin membrane wrapping of CNS axons by $\mathrm{PI}(3,4,5) \mathrm{P} 3$-dependent polarized growth at the inner tongue. Cell 156:277-290. CrossRef Medline

Srinivasan L, Sasaki Y, Calado DP, Zhang B, Paik JH, DePinho RA, Kutok JL, Kearney JF, Otipoby KL, Rajewsky K (2009) PI3 kinase signals BCRdependent mature B cell survival. Cell 139:573-586. CrossRef Medline

Trapp BD, Peterson J, Ransohoff RM, Rudick R, Mörk S, Bö L (1998) Axonal transection in the lesions of multiple sclerosis. N Engl J Med 338: 278-285. CrossRef Medline

Tumaneng K, Russell RC, Guan KL (2012) Organ size control by Hippo and TOR pathways. Curr Biol 22:R368-R379. CrossRef Medline

Viader A, Golden JP, Baloh RH, Schmidt RE, Hunter DA, Milbrandt J (2011) Schwann cell mitochondrial metabolism supports long-term axonal survival and peripheral nerve function. J Neurosci 31:10128-10140. CrossRef Medline

Yuan X, Chittajallu R, Belachew S, Anderson S, McBain CJ, Gallo V (2002) Expression of the green fluorescent protein in the oligodendrocyte lineage: a transgenic mouse for developmental and physiological studies. J Neurosci Res 70:529-545. CrossRef Medline 